\title{
Limiting too-big-to-fail: market reactions to policy announcements and actions
}

\author{
Mario Bellia $^{1}$ (1) $\cdot$ Sara Maccaferri ${ }^{2} \cdot$ Sebastian Schich $^{3}$
}

Accepted: 11 May 2021 / Published online: 14 August 2021

(c) The Author(s) 2021

\begin{abstract}
Banks considered too-big-to-fail (TBTF) tend to benefit from funding cost advantages as their debt is considered implicitly guaranteed by public authorities, even if the latter have undertaken substantial effort to limit TBTF. This paper focuses on the changes in related market perceptions in response to bank regulatory and resolution reform announcements as well as actual failure resolution actions. It analyses how premia on risky bank debt have reacted to such events, using data for senior and subordinated debt CDS quotes for 45 European banks from January 2007 to May 2020. The empirical results are consistent with progress being made in reducing the value of implicit bank debt guarantees, especially on subordinated bank liabilities. Some earlier bank failure resolution actions appeared to significantly raise risk premia, although more recent failure resolution cases either had no effect on risk premia or moved them in the opposite direction. Several of these events consisted of no-action, that is, in particular, they did not entail any bail-in. As opposed to resolution actions, the reactions of risk premia to policy and regulatory announcements are more difficult to explain and no clear pattern seems to be emerging, confirming the view that action speaks louder than words.
\end{abstract}

Keywords Too-big-to-fail $\cdot$ Implicit guarantee $\cdot$ Credit default swap $\cdot$ Event study

JEL Classification E61 $\cdot \mathrm{G} 14 \cdot \mathrm{G} 21$

S. Maccaferri was with the European Commission, Joint Research Centre (JRC) when the work started; S. Schich was with the OECD when the collaboration work with the European Commission Joint Research Centre started. The current version of the paper has benefited from comments from Stephen Lumpkin, Asani Sarkar, the Editor and two anonymous referees.

Disclaimer The opinions expressed are those of the authors only and should not be considered as representative of the European institutions. Possible errors and omissions are those of the authors.

Mario Bellia

mario.bellia@ec.europa.eu

Sara Maccaferri

s.maccaferri@be-tse.it

Sebastian Schich

s.schich@eib.org

1 European Commission - Joint Research Centre, Ispra, Italy

2 Be Consulting, Milan, Italy

3 European Investment Bank, Kirchberg, Luxembourg

\section{Introduction}

Banks that are considered too-big-to-fail (TBTF) tend to encounter more favourable financing conditions than entities that do not benefit from such a perception. The resulting funding advantage is commonly referred to as an implicit guarantee. Current reforms aim to make bail-in rather than bail-out the norm. Thus, to the extent that reforms are successful and credible, the value of implicit guarantees will decline or even disappear altogether. Bearing this interpretation in mind, the value of implicit guarantees becomes one of several indicators of financial regulatory reform progress. The Financial Stability Board (FSB) assessed in 2019/2020 the progress in limiting TBTF and, as part of that work, produced and analysed a variety of estimates of the value of implicit bank debt guarantees. Its report points to declining but not disappearing values of implicit bank debt guarantees [13].

The present report does not attempt to produce yet another set of estimates for the value of implicit guarantees. Instead, it focuses on market perceptions of regulatory and 
resolution reform announcements and policy actions, drawing for the identification of such events on previous studies and updating them, and asking how the premia in different types of risky bank debt have reacted to such events. The paper considers data on credit default swaps (CDS) from 1 January 2007 to end of May 2020, for senior unsecured and subordinated bank debt of about 45 European banks. It asks whether the movement of risk premia in these instruments around these regulatory and resolution reform announcements and actions is consistent with progress in limiting the value of implicit bank debt guarantees. Section 2 explains why implicit bank debt guarantees arose and discusses challenges in the estimation of their levels. Data used in the empirical analysis and the methodology are presented in Sect. 3. Section 4 analyses how selected bank failure resolution actions were reflected in changes in risk premia on bank debt. Section 5 compares the effect of such actions with those of announcements in regulatory and resolution regime changes, inspired by [28] who suggest that "actions speak louder than words". The list of events includes events considered in previous empirical studies as well as updates based on the press releases of the Single Resolution (SRB). Section 6 discusses issues regarding transparency and Sect. 7 concludes.

\section{Challenges in estimating and communicating about implicit guarantees}

\section{Estimation challenges}

Banks that are considered too-big-to-fail (TBTF) tend to experience more favourable financing conditions than entities that do not benefit from such a perception (as reviewed, for example, in [13], especially Annex E, and [30]). The resulting funding advantage is commonly referred to as an implicit guarantee and, sometimes, as an implicit subsidy, as there is no premium paid in exchange, at least not explicitly. Such implicit subsidies are economically distortive and adversely affect risk taking and competition, which is why policy makers have announced their intention to rein in their value. That said, policies typically do not target such values directly. The financial regulatory reform measures that have been put in place in reaction to TBTF are primarily geared towards reducing the moral hazard and limiting systemic risks that arise when banks become so large, complex or interconnected that their failure would have undesirable real economic costs.

These concepts are difficult to assess empirically and there are no commonly agreed indicators, which complicates the monitoring of related progress. What distinguishes an implicit guarantee from an explicit one is the nature of the obligation on the part of the guarantor. This obligation is explicitly stated in a contract or is recognised by law in the case of an explicit guarantee. By contrast, in the case of an implicit guarantee, the guarantee is not plainly or directly stated. Rather, it is implied, understood or suggested by some wording or by past actions. An important observation in this context is that current regulatory and resolution reforms aim to make bail-in rather than bail-out the norm. Thus, to the extent that reforms are successful and credible, the value of implicit guarantees should decline or even disappear altogether. Bearing this interpretation in mind, one can view the value of implicit guarantees as an indicator of financial regulatory reform progress.

[30], based on the results of a survey in 2014 of selfassessments of financial regulatory reforms among members and partners of the OECD Committee on Financial Markets (CMF), noted that public authorities had not settled on a best way to measure such guarantees. That said, authorities nonetheless agreed that it is important to produce various estimates of the value of such guarantees, so as to facilitate the task of assessing progress in bank regulatory reform and reducing the value of these perceived guarantees. The present section presents some estimates of such values, while the remainder of the report focuses on changes in bank debt risk premia that would be consistent with a compression of such values (the desired outcome) or an increase in such values.

Implicit guarantees, like explicit ones, have value to the extent that they are perceived to exist and that there is a non-trivial chance of their being exercised. Arguably, the initial policy response to the global financial crisis, which included the introduction of a variety of new officially supported guarantees and other support measures for banks and other financial institutions and the extension of existing explicit guarantees, further entrenched the perception that bank liabilities benefit from an implicit guarantee provided by public authorities.

Subsequent policy reforms, even if not explicitly targeting the value of implicit bank debt guarantees, are expected to limit their value. In particular, the post-crisis TBTF reforms are intended to reduce the probability of systemic crises, strengthen the buffers at the level of individual firms and facilitate their smooth resolution in case of failure. One measure in assessing progress in this regard is the value of implicit bank debt guarantees (Fig. 1).

Implicit guarantees for bank debt exist for the following reasons. Banks are much more leveraged than other firms and they are closely linked to each other through lending and derivatives transactions, so that the failure of one bank may trigger a chain of subsequent failures. Even beyond direct links, the failure of one bank can undermine the confidence in other banks that are seen as presenting similar vulnerabilities and, therefore, trigger runs on unaffiliated banks. In 


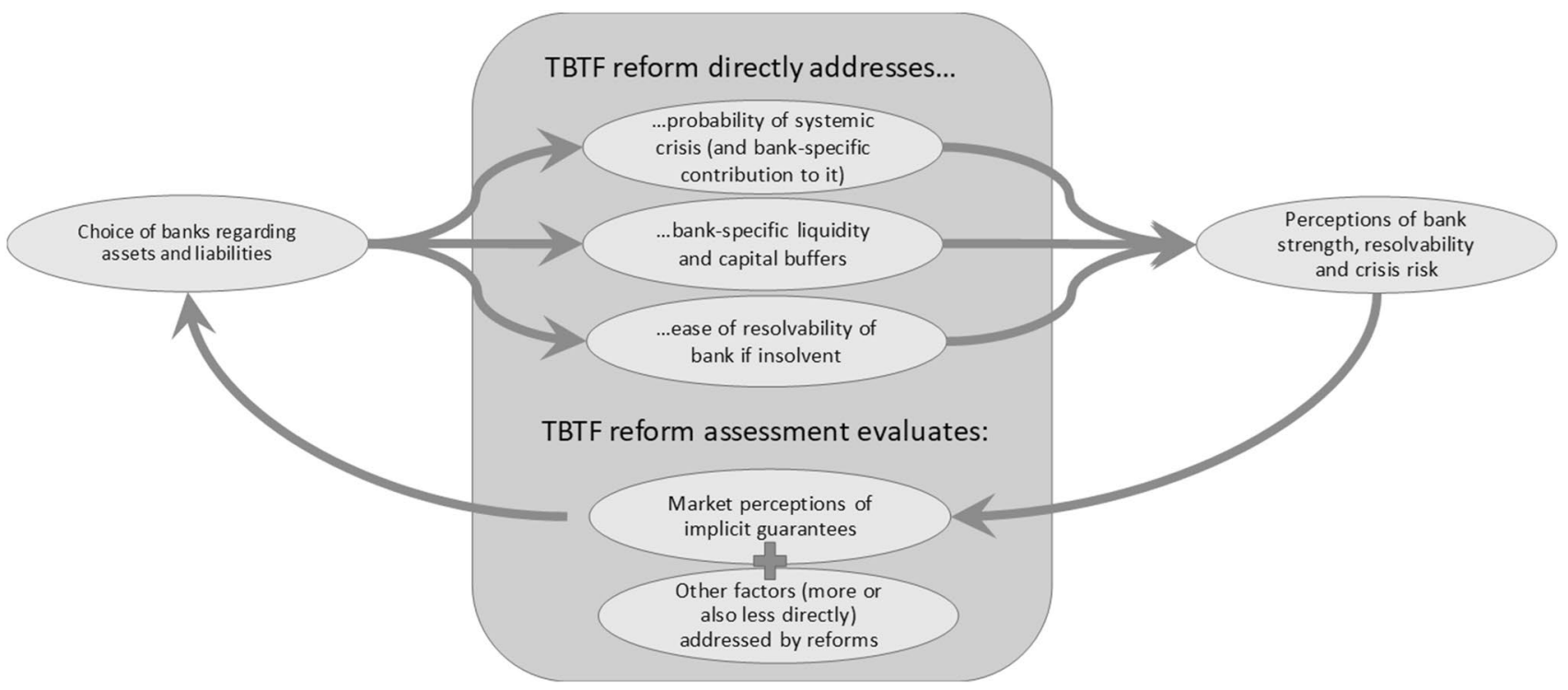

Fig. 1 TBTF reforms, implicit guarantees and TBTF reform evaluation Note: Stylised representation of the role of the concept of implicit guarantees as part of TBTF policy reforms. For simplicity, the stylised description abstracts from the role and strength of the perceived guarantor

practice, it is notoriously difficult to know for sure whether a bank's failure will remain an idiosyncratic event, which explains why concerns for the system can quickly arise. Beyond such concerns for the stability of the system, public authorities might consider the costs of bank default unacceptably high for other reasons. For example, a bank might be considered important for specific financial market segments seen as worth protecting for other policy reasons (e.g. to allow the development of securitised mortgage markets) or when a bank's creditors are considered worth protecting (e.g. small and presumably unsophisticated households).

Absent an effective and well-functioning resolution framework capable of smoothly unwinding any bank, regardless of its size, role or complexity, and without generating wider adverse repercussions, a time inconsistency problem is likely to exist. Even when the presumed guarantor ex ante has an expressed intent not to provide support to any bank, subsequent events might make it optimal to renege on such announcements ex post. As long as it is not possible to definitely rule out that support will be provided to avoid a systemic threat or harm to unsophisticated savers, an implicit guarantee will have an economic value. This situation, in turn, provides incentives for bank managers and owners to expand activities so as to maximise the value of the implicit guarantee.

The effect of a guarantee on risky debt is to transfer risk from the creditor to the guarantor, although in the case of an implicit guarantee the transfer is not certain but perceived. The counterparties of banks thus assign a lower risk premium than they would in the absence of implicit guarantees, and as a result, funding costs for such entities are artificially low. This situation creates economic costs. In particular, as long as debtors are exposed to the risk of loss on their claims (or delayed access to funds), they can be expected to impose market discipline on their debtor. Implicit guarantees, however, tend to weaken market discipline. They distort the incentives of bank owners and managers leading them to take additional risks and also distort the incentives on the part of creditors and other bank counterparties to monitor and discipline the former. Where effective market discipline is absent, an essential tool to control risk taking is lost [6]. In fact, most empirical evidence is consistent with the hypothesis that banks tend to increase their risk taking in the presence of implicit guarantees for their debt, thus leading to "too-much" of an increase in bank balance sheet size. The availability of underpriced guarantees tends to create an incentive for both additional bank risk taking and sector leverage, and this situation gives rise to negative externalities emanating from the banking sector to the rest of the economy in the form of higher probability of default and higher level of systemic risk [1]. Hagendorff et al. [18] provide empirical evidence consistent with the view that implicit bank debt guarantees are one explanation for the observation that relatively large banks expose themselves to higher tail risks. As with any guarantee for which there is no adequate fee, distortions to incentives and competition are being created, which reinforce each other. Losses of excessive risk taking may actually be eventually socialised, while the gains accruing in the meantime remain private. The value of the implicit guarantee reflects bank-specific characteristics, such as its extent of fragility, as well as the strength of the sovereign seen as providing the guarantee 


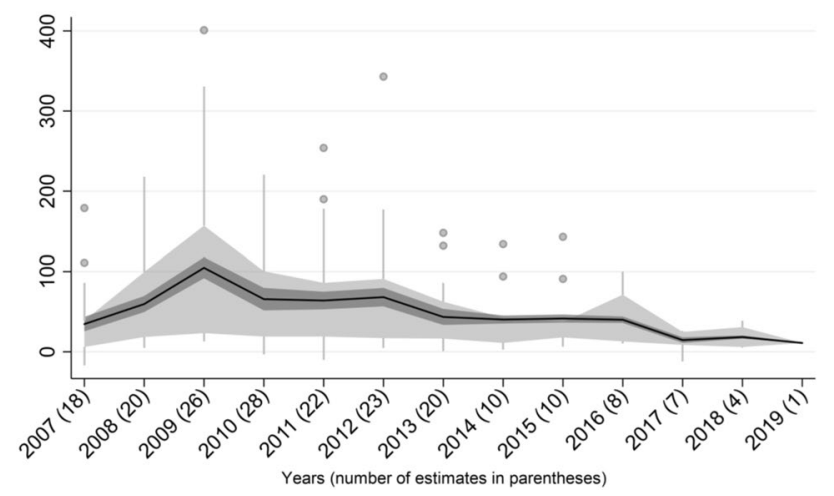

Fig. 2 Selected estimates of funding cost advantages (basis points of interest rates) Note: Number of estimates for each year shown in parentheses, with individual estimates being listed in Appendix A (note that several studies produce more than one estimate per any specific year). Light grey shaded area shows the interquartile range and the horizontal line the arithmetic average. Vertical lines represent the whiskers in a boxplot, i.e. the values that are adjacent to the 75 quartile. Dots indicate outliers. Dark grey shaded band is proportional to the number of estimates, implying that average point estimates that are part of a broader band are more reliable that those that are part of a narrower band. Source: Update from [30]

[12]. This observation has received special attention in Europe, where the presence of implicit bank debt guarantees supposedly being provided by domestic sovereigns has tended to reinforce the close and adverse interrelationships between the values of domestic sovereign and banking sector debt. Another aspect of that relationship is that implicit guarantees can also have potentially adverse effects on the perceived guarantor. Perceived guarantees are seen as creating contingent fiscal liabilities for the "guarantor", which can be substantial [3, 15]). Moreover, they can become real contingent liabilities if events force the conversion of the implicit guarantee into an explicit one and become actual liabilities if the bank in question fails to pay its own debt.

What types of bank debt benefit from an implicit guarantee is not clear a priori, and the perimeter appears to be changing over time. ${ }^{1}$ Current post-crisis regulatory reforms emphasise the traditional principle that there exists a waterfall of bank liabilities that should be bailed in in situations of failure resolution, with subordinated creditors being in line to share in the losses before senior unsecured creditors.

Estimating the value of implicit bank debt is challenging, and so is communicating about progress in limiting such values (Sect. 2.2). There exists no generally accepted method and different methods tend to yield different results. Estimates also differ depending on the type of debt and size of banks considered, the geographical focus and the sample period. Figure 2 illustrates how estimates from selected

$\overline{1}$ See also the discussion in Sect. 6 about "constrained bail-in". different studies have evolved over time; it is consistent with a broad downward trend in the value of implicit guarantees since the peak attained about a decade ago. Similarly, estimates by the Financial Stability Board (FSB) point to a declining, but not disappearing, values of implicit bank debt guarantees, even though it is not clear whether they have fallen significantly below their pre-crisis levels.

\section{Challenges in communicating about implicit guarantees}

There is consensus among policy makers that implicit guarantees are undesirable and that lower levels are preferable to higher ones $[11,25]$. There is recent evidence that progress has been made in this regard [13]. That said, whether or not current levels are below or above those observed before the crisis is not always clear and seems to depend on the method used as well as on the bank sample, including the choice of jurisdictions represented. According to [30], many public authorities rely at least partly on credit rating agency data to extract measures of the credit rating uplift due to assumed government support, while others focus directly on the costs of funding for banks using observed market prices on debt or equity (or on returns on these). The observation that no consensus exists regarding a best estimation method obviously complicates policy makers' communication about progress made in limiting the value of implicit guarantees. In any case, it is clear that the estimated value of implicit bank debt guarantees is not a direct target of regulatory reforms and policy actions. Nonetheless, the question arises as to what decline in value would be considered consistent with the statement that "considerable reform progress" has been made. Such assessments in turn can increase transparency and enhance the credibility of bank failure resolution reforms, as also discussed in Sect. 6. Four key challenges affect policy makers' communication about progress in limiting the value of implicit guarantees.

First, estimates of the value of implicit guarantees are estimates; they are thus uncertain. The uncertainty might be particularly pronounced for the following reason. Such estimates reflect expectations about policy actions and considerations in the situation in which an uncertain event occurs; it is thus a conditional expectation. Statistically, each possible outcome on a one-dimensional distribution regarding the outlook for a bank needs to be qualified by yet another distribution describing the range of future actions contingent on that event occurring. In practice, different types of data can be and are used in practice in producing related estimates. There is no single preferred method, which is why it is advisable to use more than one method. Different methods can give vastly different results, however (see, for example, [5]). Thus, communication about such a range of estimates is challenging. 
Second, there is the potential for undesirable feedback effects. By communicating about the existence and value of implicit guarantees, policy makers may find themselves creating or further entrenching such perceptions, which is undesirable. This observation explains in part why there is reluctance on the part of authorities in associating themselves with, and communicating about, their own estimates of implicit guarantees. Such "own" estimates could be interpreted as effectively making explicit what is at best implicit. ${ }^{2}$ The implications of reinforcing such expectations differ depending on the strength of the guarantor. In situations where that strength is already questioned, an undesirable feedback loop could evolve, with mutually reinforcing adverse effects on perceptions of the strength of domestic banks and the sovereign. This observation explains in part why there is some reluctance, including in internationally coordinated public authority efforts to stress heterogeneity in progress among jurisdictions but rather to focus on broad aggregate developments.

Third, with the exception of Lehman Brothers, no major bank has failed over the past decade or so. Since the concept of G-SIBs was introduced in 2011, no entity with that label has failed. Statistical evidence supporting the view that such cases can be resolved without causing severe real economic costs is simply not readily available. This observation is comforting per se as reforms specifically aim to limit moral hazard, excessive risk taking and the build-up of systemic risk, so as to avoid financial instability. But it also implies that a statement on progress in limiting TBTF and implicit guarantees simply cannot be based on the results of a rigorous statistical analysis of a sample data set that includes failures.

Fourth, the institution-specific contribution to the value of implicit bank debt guarantee is difficult to disentangle from the systemic crisis risk. Conceptually, implicit guarantees can be interpreted as (perceived) put options. Even if the belief prevails that an implicit bank debt guarantee exists, market price-based estimates of its value might suggest a declining value when the likelihood of a crisis recedes. The guarantee simply moves further out of the money similar to a put option [34]. As a result of these various observations, there is some reluctance on the part of public authorities to report on absolute levels of estimates. Rather, there is a preference for reporting on and placing relatively more emphasis on estimates of changes over time. That choice is understandable given estimation uncertainties and other considerations. For example, methodological choices might

\footnotetext{
2 In this context, note that to alleviate related concerns, the OECD survey from 2014 [30] did not ask authorities to necessarily share their own estimates of the value of implicit guarantees, but to indicate whether they "were aware of any credible estimates", and what these estimates implied.
}

also imply that preference. A commonly used approach is the difference-in-difference approach, which by construction allows one to draw firm conclusions regarding changes rather than levels based on statistical inference. That said, the focus on changes in communications might create tensions with expectations on the part of the general public, which is likely to expect more than a mere statement that "much progress" has been made; some pointers to where one stands in absolute terms or compared to the pre-crisis period might be expected. The current report circumvents these difficulties by focusing in particular on changes in estimates of somewhat abstract concepts.

\section{Data and methodology}

The aim of recent financial regulatory reform is to arrive at a situation in which bail-out is replaced by bail-in and where market participants understand that bank failure resolutions will be characterised by the application of bail-in of creditors. In fact, holders of unsecured bank debt in some countries have incurred losses, and where such losses occurred, there is evidence of a decline in the value of implicit bank debt guarantees. Schäfer et al. [28] suggest that such cases of bail-in are associated with strong market reactions in terms of rising risk premia on credit default swaps and a drop in stock returns. These observations are consistent with reduced bail-out expectations and hence a more limited value of implicit bank debt guarantees.

To assess the movement of risk premia around regulatory and resolution reform announcement and action, we rely on two well-known traded market instruments, CDS and equity prices. Data on spreads ${ }^{3}$ of single-name CDS on senior and subordinated debt are obtained from the Intercontinental Exchange (ICE) of CMF Datavision and Thomson Reuters Datastream, with the latter providing us in particular data that is based on the revised restructuring clause introduced in 2014. The initial sample consists of single-name CDS on senior and subordinated debt of 131 European banks. All contracts considered are in Euros and have a maturity of five years. We apply several data quality checks and cleaning procedures to the initial raw dataset, given that during our sample period, banks changed their names, merged or were acquired by other entities. Moreover, data were not available for all banks for each date, with subordinated debt being available for fewer banks than senior debt CDS quotes. Data on CDS spreads are available on daily basis from 1 January 2007 to end of May 2020 for 89 banks in the case of senior

\footnotetext{
${ }^{3}$ We use interchangeably the terms "CDS quotes", "CDS prices" and "CDS spreads", although we observe bid and ask quotes of CDS and use the mid quotes of these two.
} 
and 65 banks in the case of subordinated debt. ${ }^{4}$ Equity prices are closing prices obtained from Bloomberg and are available for 55 banks. Merging the CDS and equity prices datasets, the final dataset includes 44 banks with observations for all three variables (that is, senior and subordinated CDS spreads and equity prices) spanning from January 2007 to May 2020. The sample is biased towards large banks that are considered systemic either at the global or domestic level, given that large banks are more likely to be the reference entity of CDS contracts and/or have quoted equity. In fact, 14 banks are considered (always) as G-SIBs and 17 banks are considered by EBA as "Other Systemically Important Institutions" (starting from 2015), while 13 banks are not considered large, complex or interconnected enough to be identified as systemically important.

For what concerns the methodology, we estimate a set of panel regressions on equity and CDS price changes where we also include controls for different characteristics of the bank (size and systematic importance status), market conditions and the respective sovereign creditworthiness. This methodology allows us to estimate the effects of the various events in a single specification and compare the effects across different types of events and, in addition, to compare the effects of the events across different groups of banks. Previous studies (for example, [28]) applied seemingly unrelated regression (SUR) analysis event by event, which effectively becomes an OLS estimation bank by bank as long as the explanatory variables on the right-hand side are the same. This approach thus only partially capture the information available from other events (that is those outside of that estimation window) in estimating the coefficients for any specific event under consideration. By contrast, we consider a panel regression approach that captures the effect of a specific event taking into account the information from the estimation of all the other events. Our work also differs from previous empirical studies in that events considered in different studies are combined in one single study. Moreover, we categorise these events as either "actions" (resolution action or no-action) or "announcements" (regulatory and policy announcements) and distinguish between different types of regulatory and policy announcements events considered in, categorisation of events and the regression methodology used. The distinction between "actions" and

\footnotetext{
${ }^{4}$ A few specific decisions are taken. Dexia CDS quotes reacted very strongly and adversely to the sale of Dexia Bank Belgium to the Belgian State and the subsequent orderly resolution plan by the European Commission of end 2012. These quotes appear not to be representative of actual trades, and thus, Dexia is excluded from the dataset. Also, Natixis and BPCE, Banque Populaire and Caisse d'Epargne merged in 2012, and the dataset considers data for Natixis until 2015 and BPCE after 2015 to form a single series for newly formed BPCE Group.
}

"announcements" is motivated by the suggestion in [28] that "actions speak louder than words". Admittedly, the "actions" considered in the main text also are communicated via announcements, although a key difference is that they refer to specific resolution cases as opposed to other announcements that refer to more general policy or regulatory changes.

As regards the explanatory variables, we consider a set of dummies, one for each event, that takes the value of one around the event dates and zero otherwise. Three types of groups of banks are distinguished, namely global systemically important banks (referred to here as G-SIBs), other systemically important banks (referred to here as O-SIBs, which are other systemically important institutions or O-SIBs as defined by the European Banking Authority ${ }^{5}$ ), and non-systemically important banks (referred to here as non-SIBs). G-SIBs are banks that are always included in the G-SIB list published by the FSB (14 banks). O-SIBs are banks that might or might be part of the FSB G-SIB list but in any case are always included either as part of that FSB G-SIB list or the EBA O-SIB list (17 banks). The remaining banks are not considered systemically important (13 Institutions). Even if the assessments regarding systemic importance have been introduced only in 2011 (FSB list of G-SIBs) and 2015 (EBA list of O-SIBs) and are subject to change during our sample period, we keep the constituents of each of the three groups as defined above constant throughout the sample period (from 2007 to 2020). Formally, we estimate the following model:

$$
\begin{aligned}
R_{i, t} & =\alpha_{0}+\beta_{1} R_{m, t}+\beta_{n} D_{t, n}+\beta_{2} \operatorname{GSIB}_{i}+\beta_{n}\left(D_{t, n} * \operatorname{GSIB}_{i}\right)+ \\
& +\beta_{3} \operatorname{OSIB}_{i}+\beta_{m}\left(D_{t, n} * \operatorname{OSIB}_{i}\right)+\beta_{4} T A_{i, t}+\beta_{5} \operatorname{SOV}_{i, t}+\epsilon_{i, t}
\end{aligned}
$$

with $E\left[\epsilon_{i, t}\right]=0$ and $\operatorname{Var}\left(\epsilon_{i, t}\right)=\sigma_{\epsilon}^{2}$, where $R_{i, t}$ represents the return (CDS first difference or log return for equity) for the bank $i$ at time $t, \alpha_{0}$ the intercept term, $R_{m, t}$ represents the return of the market, SSIB $_{i}$ a dummy that takes the value of 1 if the bank is considered G-SIB and zero otherwise, $O S I B_{i}$ a dummy that takes the value of 1 if a bank is considered O-SIB and zero otherwise.

The variable $D_{t, n}$ represents in fact a set of $\mathrm{n}$ dummy variables, one for each event. Each dummy variable takes on the value of 1 for the three days surrounding the event, i.e. one day before, the event day and one day after; otherwise, it is zero. The choice of the interval is consistent with previous works in the topic (among others, [28]. The $n$ interaction terms $D_{t, n} * G S I B_{i}$ and $m$ interaction terms $D_{t, n} * O S I I_{i}$ allow us to test the null hypothesis that the average return of the G-SIB differs from the two other groups and that

\footnotetext{
5 See https://eba.europa.eu/risk-analysis-and-data/other-systemicallyimportant-institutions-o-siis-.
} 
the average return of the O-SIBs differ from the two other groups, respectively. If the coefficients of these interaction terms are statistically significant, they can be used to assess the size and direction of the effect on the respective group compared to the other banks (e.g. in the case of $D_{t, n} * G S I B_{i}$ as compared to both O-SIBS and non-SIBS combined). To control for bank size and the role of its domestic sovereign, respectively, we include $T A_{i, t}$, the logarithm of (annual) total asset of each bank, and $S O V_{i, t}$, the return on the CDS of the banks' domestic sovereign (thus a country-specific variable). Finally, $\epsilon_{i, t}$ is the error term with zero mean and variance equal to $\sigma_{\epsilon}^{2}$. The market index considered is the same for all banks; thus, the model can be estimated using (a panel of) ordinary least squares. Thus, summarising, the model captures the average abnormal returns in the days surrounding the events, while controlling for the country riskiness related to each bank. Robust standard errors are obtained through clustering at the bank level. The results are shown as part of the main text.

We also run another specification of the model in order to assess the difference in the reaction of domestic banks vis-àvis other banks in the case of events that are country-specific (i.e. no G20 announcements etc.), with results being shown in Appendix B. This model is as follows:

$$
\begin{aligned}
R_{i, t}= & \alpha_{0}+\beta_{1} R_{m, t}+\beta_{n} D E_{t, n}+\beta_{n} D D_{t, n}+\beta_{n}\left(D D_{t, n} * \operatorname{COUNTRY}_{i}\right) \\
& +\beta_{3} T A_{i, t}+\beta_{4} S O V_{i, t}+\epsilon_{i, t}
\end{aligned}
$$

with $E\left[\epsilon_{i, t}\right]=0$ and $\operatorname{Var}\left(\epsilon_{i, t}\right)=\sigma_{\epsilon}^{2}$, where the dummy COUNTRY $Y_{i}$ identifies the country where the bank is located, i.e. whether it is a domestic (taking the value of one) or nondomestic bank (value of zero). The dummy $D E_{t, n}$ includes all events that are not country-specific, while the dummy $D D_{t, n}$ identify the event that can be related to a single country. The interaction term $D D_{t, n} * \operatorname{COUNTRY}_{i}$ allows us to assess whether the domestic banks are reacting differently compared to the non-domestic banks. All tables report the marginal effect at means, or the marginal coefficient, that allows one to assess the change in a dependent variable (in our case, the return of equity prices or change the difference in the CDS quote) in response to a change in the covariates, that is the event dummies and control variables. The calculation of the margins allows one to display and isolate the overall effect of the events and, given the specification of the regression and the interaction terms added, also to assess the effect of the events for different types of banks (G-SIBs, O-SIBs and non-SIBs). The marginal coefficients for the subgroups can be interpreted as the coefficient of a panel regression estimated only for that subset of banks. The advantage of adopting this approach is that the estimates captures the overall effect of the events on all banks, but also allows one to control for heterogeneity across types of banks. The coefficients are thus comparable across types of banks, although the total effect is not the sum of the marginal effects for the different types of banks given the presence of cross-correlations of explanatory variables. The full panel regressions are available upon request. Section

\section{Market reactions to policy actions}

Considering the bail-in events identified in the [28], while also adding more recent observations based on press releases issued by the Single Resolution Board (SRB) and the European Commission (EC), ${ }^{6}$ Table 1 describes market reactions to these events. To facilitate the comparison of results for changes in equity and CDS prices, the latter are multiplied through by minus one. Thus, negative estimates reflect an increase (rather than decrease) in risk premia in bank debt CDS spreads. Hence, such negative coefficient estimates for CDS prices have a similar interpretation as similar estimates for equity price changes, that is they are "bad news" for bank counterparties. There are some instances of strong increases in risk premia on either senior or subordinated debt CDS, which is consistent with a reduction in the value of implicit bank debt guarantees. Examples include the Spanish bank rescue plan, which implied a bail-in of junior debtors and was associated with a strong increase in subordinated CDS spreads, and the nationalisation of SNS Reaal in the Netherlands, which was associated with significant increases in senior debt CDS.

\footnotetext{
${ }^{6}$ According to the SRB, resolution is the application of one or more resolution tools to a bank in order to achieve the resolution objectives and occurs when the authorities determine that (i) the bank is failing or likely to fail, there are no supervisory or private sector measures that can restore the bank to viability within a short timeframe; and resolution is necessary in the public interest, i.e. the resolution objectives would not be met to the same extent if the bank were wound up under normal (national) insolvency proceedings. Subsequently, the SRB announces the adoption of either its decisions to adopt a resolution scheme or not to take resolution action. For each decision, the SRB publishes a press release. These are considered here as events, and they include the following ones. On 7 June 2017, the SRB transferred all shares of Banco Popular to Santander. Events also include Banca Popolare di Vicenza S.p.A. and Veneto Banca S.p.A on 23 June 2017 and ABLV Bank on 24 February 2018. Also, on 15 August 2019, following the European Central Bank's assessment of AS PNB Banka as failing or likely to fail, the SRB decided that resolution action was not necessary, noting that the bank would be wound up under national law. On 18 March 2020, the SRB decided that there is no compensation due to Banco Popular shareholders and creditors, finding that insolvency would have been more costly. Further to these events, we also included three more events in our analysis. They are the "precautionary recapitalisation" of Banca Monte dei Paschi on 29 December 2016, the European Commission (EC) announcement of its approval of the "precautionary recapitalisation" of Banca Monte dei Paschi on 4 July 2017, and the EC decision on 5 December 2019 that recapitalisation of German NordLB is not state aid.
} 
Table 1 Market reactions to selected decisions regarding (potential) bank failure resolution

\begin{tabular}{|c|c|c|c|c|}
\hline Date/Event ID & Event & Equity & Senior & Subord \\
\hline $\begin{array}{l}6 \text { Feb } 2011 \\
/(\mathrm{E} 1)\end{array}$ & Bail-in of senior debtors of Amagerbanken in Denmark & $\begin{array}{l}0.003 * * \\
(0.001)\end{array}$ & $\begin{array}{l}0.341 \\
(0.337)\end{array}$ & $\begin{array}{l}0.143 \\
(0.710)\end{array}$ \\
\hline $\begin{array}{l}10 \mathrm{Jul} 2012 \\
\text { / (E2) }\end{array}$ & Spanish bank rescue plan implies bail-in of junior creditors & $\begin{array}{l}-0.001 \\
(0.001)\end{array}$ & $\begin{array}{l}-1.859 * \\
(1.017)\end{array}$ & $\begin{array}{l}-10.452 * * * \\
(2.377)\end{array}$ \\
\hline $\begin{array}{l}19 \mathrm{Jul} 2012 \\
\text { / (E3) }\end{array}$ & German government back Spanish rescue plan foreseeing bail-in of junior creditors & $\begin{array}{l}-0.009 * * * \\
(0.002)\end{array}$ & $\begin{array}{l}-1.062 \\
(1.279)\end{array}$ & $\begin{array}{l}-5.447 * * \\
(2.621)\end{array}$ \\
\hline $\begin{array}{l}23 \text { Aug } 2012 \\
\text { / (E4) }\end{array}$ & Spanish authorities clearly express intent to implement national bank resolution law & $\begin{array}{l}0.002 \\
(0.002)\end{array}$ & $\begin{array}{l}0.890 \\
(1.159)\end{array}$ & $\begin{array}{l}-2.072 \\
(2.144)\end{array}$ \\
\hline $\begin{array}{l}1 \text { Feb } 2013 \\
\text { / (E5) }\end{array}$ & Nationalisation of SNS Reaal in the Netherlands & $\begin{array}{l}-0.006^{* * *} \\
(0.002)\end{array}$ & $\begin{array}{l}-2.055^{* * *} \\
(0.392)\end{array}$ & $\begin{array}{l}-4.175^{* * *} \\
(1.456)\end{array}$ \\
\hline $\begin{array}{l}11 \text { Feb } 2013 \\
\text { / (E6) }\end{array}$ & Euro area finance ministers consider bail-in of senior debt as option for Cyprus banks & $\begin{array}{l}0.009 * * * \\
(0.003)\end{array}$ & $\begin{array}{l}1.041 * * \\
(0.519)\end{array}$ & $\begin{array}{l}2.370 * * * \\
(0.479)\end{array}$ \\
\hline $\begin{array}{l}18 \text { Mar } 2013 \\
\text { / (E7) }\end{array}$ & Cyprian proposal to introduce levy including on insured Cyprian bank depositors & $\begin{array}{l}-0.011 * * * \\
(0.001)\end{array}$ & $\begin{array}{l}-3.683 * * * \\
(0.456)\end{array}$ & $\begin{array}{l}-4.964 * * * \\
(0.733)\end{array}$ \\
\hline $\begin{array}{l}25 \text { Mar } 2013 \\
\text { / (E8) }\end{array}$ & Bail-in of senior debtors of Cyprian banks & $\begin{array}{l}-0.015^{* * *} \\
(0.002)\end{array}$ & $\begin{array}{l}-3.749 * * * \\
(0.887)\end{array}$ & $\begin{array}{l}-5.432 * * * \\
(0.875)\end{array}$ \\
\hline $\begin{array}{l}4 \text { Aug } 2014 \\
\text { / (E9) }\end{array}$ & Creditor bail-in in the case of Banco Espirito Santo, Portugal & $\begin{array}{l}-0.003 \\
(0.002)\end{array}$ & $\begin{array}{l}1.625^{*} \\
(0.845)\end{array}$ & $\begin{array}{l}1.912 * \\
(1.154)\end{array}$ \\
\hline $\begin{array}{l}29 \text { Dec } 2016 \\
\text { / (E10) }\end{array}$ & "Precautionary recapitalisation" of Banca Monte dei Paschi & $\begin{array}{l}-0.005^{* * *} \\
(0.001)\end{array}$ & $\begin{array}{l}0.522 * \\
(0.282)\end{array}$ & $\begin{array}{l}1.162 * * \\
(0.552)\end{array}$ \\
\hline $\begin{array}{l}7 \text { Jun } 2017 \\
\text { / (E11) }\end{array}$ & SRB transfers all shares and debt of Banco Popular Español to Banco Santander & $\begin{array}{l}0.005 * * * \\
(0.001)\end{array}$ & $\begin{array}{l}0.615^{* * *} \\
(0.175)\end{array}$ & $\begin{array}{l}1.464 * * \\
(0.697)\end{array}$ \\
\hline $\begin{array}{l}23 \text { Jun } 2017 \\
/(\text { E12) }\end{array}$ & SRB not to take resolution action re Banca Popolare di Vicenza and Veneto Banca & $\begin{array}{l}-0.001 * * \\
(0.001)\end{array}$ & $\begin{array}{l}1.286 * \\
(0.657)\end{array}$ & $\begin{array}{l}3.783 * * * \\
(0.724)\end{array}$ \\
\hline $\begin{array}{l}4 \text { Jul } 2017 \\
\text { / (E13) }\end{array}$ & EC announced the approval of the precautionary recapitalisation of MPS & $\begin{array}{l}0.005 * * * \\
(0.001)\end{array}$ & $\begin{array}{l}-0.002 \\
(0.188)\end{array}$ & $\begin{array}{l}-1.365^{* *} \\
(0.637)\end{array}$ \\
\hline $\begin{array}{l}24 \text { Feb } 2018 \\
/(\text { E14) }\end{array}$ & SRB not to take resolution action re ABLV Bank and its subsidiary in Luxembourg & $\begin{array}{l}-0.001 * \\
(0.001)\end{array}$ & $\begin{array}{l}0.099 \\
(0.089)\end{array}$ & $\begin{array}{l}0.051 \\
(0.202)\end{array}$ \\
\hline $\begin{array}{l}15 \text { Aug } 2019 \\
/(\mathrm{E} 15)\end{array}$ & SRB not to take action re AS PNB Banka, to be wound up national law in Latvia & $\begin{array}{l}0.001 \\
(0.001)\end{array}$ & $\begin{array}{l}-0.318 * * \\
(0.148)\end{array}$ & $\begin{array}{l}-0.455^{* *} \\
(0.219)\end{array}$ \\
\hline $\begin{array}{l}5 \text { Dec } 2019 \\
/(\mathrm{E} 16)\end{array}$ & EC approves NordLB State aid & $\begin{array}{l}-0.000 \\
(0.001)\end{array}$ & $\begin{array}{l}-0.522 * * * \\
(0.087)\end{array}$ & $\begin{array}{l}-0.583^{* * * *} \\
(0.114)\end{array}$ \\
\hline $\begin{array}{l}18 \text { Mar } 2020 \\
/(\mathrm{E} 17)\end{array}$ & SRB: No compensation due to Banco Popular counterparties & $\begin{array}{l}0.000 \\
(0.003)\end{array}$ & $\begin{array}{l}0.265 \\
(0.166)\end{array}$ & $\begin{array}{l}0.141 \\
(0.334)\end{array}$ \\
\hline
\end{tabular}

Events selected based on [28] and updates based on Single Resolution Board and European Commission (EC) press releases. Results for an event window of $-1 /+1$ day, that is including three observations. "Senior" ("Subord") denotes coefficient estimates for changes in CDS price quotes for senior unsecured (subordinated) debt; all such changes are multiplied through by minus one to make the estimates comparable in interpretation to those obtained for equity prices. Thus, a negative sign means that CDS spreads are rising, which can be interpreted as "bad news" for debt holders. Source: Authors' estimates

Very significant increases in risk premia could also be observed for the events related to the bail-in of debtors of banks in Cyprus. Another observation is that the consideration on the part of Euro area finance ministers of a bail-in of senior debtors in the case of banks in Cyprus was associated with a reduction in CDS spreads on senior and subordinated debt. Similarly, the announcement by the SRB not to take resolution action with regard to Banca Popolare di Vicenza and Veneto Banca is associated with declining risk premia on both senior and subordinated debt CDS, while the reaction of equity prices was mildly, but significantly, negative. ${ }^{7}$ A remarkable observation is that failure resolution

\footnotetext{
${ }^{7}$ For many but not all events, the results for equity are consistent with those obtained for debt. Two exceptions from that observation are the announcement of the "Precautionary recapitalisation" of Banca Monte dei Paschi, where subordinated debt risk premia decreased, while equity prices also decreased significantly. A similar "opposite" reaction is observed as well for the SRB decision regarding Banca Popolare di Vicenza and Veneto Banca on 23 June 2017.
} 
actions can have effects on TBTF perceptions not just in the jurisdiction where they occur, ${ }^{8}$ but even beyond national borders (Appendix B). The results shown in Table 1 are broadly similar to [28], who conclude that the Cyprian crisis constituted a watershed regarding the bail-in of bank creditors and that the actual occurrence of a broad-based bail-in convinced investors that a regime change from bail-out to bail-in had occurred. To what extent that assessment can be extrapolated, especially given the different results obtained for more recent events, is not clear, however. In fact, more recent events (i.e. in particular "no-actions") were not associated with a significant increase in risk premia, but on the contrary sometimes even a significant decrease.

We analyse to what extent the results depend on the "type" of bank, whereby we distinguish among G-SIBs, O-SIBs and non-SIBs. The results are shown in Table 2 and the following observations are singled out for special attention.

First, there are some events for which the debt market (although not necessarily the equity market) reaction is uniform across all types of banks, such as for the Cyprian proposal to introduce a levy on insured Cyprian bank depositors (18 March 2013), the bail-in of senior debtors of Cyprian banks (25 March 2013), the SRB announcement not to take resolution actions regarding Banca Popolare di Vicenza and Veneto Banca (23 June 2017), and the SRB decision not to take action regarding AS PNB Banka (15 August 2019)

Second, for several events, there are more instances in which subordinated or senior debt CDS spreads of G-SIBs exhibit significant reactions to events as compared to CDS spreads of O-SIB or non-SIBs.

Third, for two events in the middle of our sample period (i.e. Amagerbanken bail-in on 6 February 2011 and Spanish use of bank resolution law on 23 August 2012), senior and subordinated debt of G-SIBs significantly underperform the market, while the senior debt of non-systemic banks even significantly outperforms the market. Results for more recent dates are more similar across different types of banks, to the extent the effects are significant at all. That said, for some events, they turned out to be significant only in the case of G-SIBs. For example, the SRB decision to not compensate Banco Popular shareholders and creditors on 18 February 2020 is associated with a significant increase in the risk premium for G-SIB senior debt, with no significant reaction in the case of the debt of the other types of banks, that is O-SIB

\footnotetext{
${ }^{8}$ Previous work identified evidence that in countries where legal changes were made to establish more effective resolution regimes and where, subsequently, actual failure resolutions involved losses of the part of at least some holders of unsecured bank debt, noticeable declines in the value of implicit guarantees as measured by the credit rating uplift [32] or increases in the costs of deposits for a bank [9] were observed.
}

and non-SIB banks, however. The decision by the SRB not to take resolution action regarding ABVL Bank, by contrast, is reflected in a significant decline of the risk premium in senior debt of G-SIBs, with no significant reaction in the case of other types of debt and banks.

\section{Market reactions to announcements versus actions}

\section{Market reactions to different types of announcements}

Conceptually, three policy options are available to limit the value of implicit bank debt guarantees:

- First, to strengthen banks, for example, by requiring larger and better quality capital and liquidity buffers and improved governance and risk management, so that the value of implicit guarantees declines ("making banks safer").

- Second, to strengthen the capacity of public authorities to withdraw the implicit guarantees, in particular by making failure resolution more effective and credible ("making banks more resolvable").

- Third, to charge an explicit premium in exchange for the market perception of an implicit guarantee, thus incentivising banks to reduce their "use" of this guarantee, and making themselves safer and/or more resolvable ("charging banks for implicit guarantee").

As regards the overall mix of these three policy approaches to describe their specific regulatory reforms, undertaken and planned following the global financial crisis, "making banks safer" and "making banks more resolvable" are an appropriate description of the overall gist describing their regulatory reforms (Fig. 3). Less so is "charging banks for implicit guarantee". There was a sense that given the complex nature of implicit guarantees and time inconsistency problems, simply "charging" for their value is not a feasible option to eliminate them. ${ }^{9}$ The three options are used here to categorise the policy and regulatory announcements that were considered in previous empirical event studies [21, $28,29]$. The results of a set of panel regressions considering these events, controlling for overall market conditions

\footnotetext{
9 A list of specific policy choices was offered in the survey, grouped by the three policy options mentioned above. Among the altogether 33 specific policies offered, respondents considered "producing estimates of the value of implicit bank debt guarantees and charging directly for them", again, was considered the least adequate description of their domestic policy (see [31], Figure 1).
} 
Table 2 Market reactions to actions regarding potential bank resolution across types of banks

\begin{tabular}{|c|c|c|c|c|c|c|c|c|c|}
\hline \multirow[b]{2}{*}{ Date/Event } & \multicolumn{3}{|l|}{ G-SIBs } & \multicolumn{3}{|l|}{ O-SIBs } & \multicolumn{3}{|l|}{ Non-SIBs } \\
\hline & Equity & Senior & Subord & Equity & Senior & Subord & Equity & Senior & Subord \\
\hline 6 Feb 2011 / (E1) & $\begin{array}{l}0.004 \\
(0.003)\end{array}$ & $\begin{array}{l}-1.084 * * * \\
(0.329)\end{array}$ & $\begin{array}{l}-0.928 * * \\
(0.442)\end{array}$ & $\begin{array}{l}0.003 \\
(0.002)\end{array}$ & $\begin{array}{l}0.624 \\
(0.594)\end{array}$ & $\begin{array}{l}-0.794 \\
(1.057)\end{array}$ & $\begin{array}{l}0.003 \\
(0.002)\end{array}$ & $\begin{array}{l}1.752 * * \\
(0.782)\end{array}$ & $\begin{array}{l}2.974 \\
(1.967)\end{array}$ \\
\hline 10 Jul 2012 / (E2) & $\begin{array}{l}0.000 \\
(0.002)\end{array}$ & $\begin{array}{l}-1.296^{* * *} \\
(0.412)\end{array}$ & $\begin{array}{l}-5.512 * * * \\
(0.769)\end{array}$ & $\begin{array}{l}0.002 * \\
(0.001)\end{array}$ & $\begin{array}{l}-1.550 \\
(1.276)\end{array}$ & $\begin{array}{l}-5.507 * * \\
(2.431)\end{array}$ & $\begin{array}{l}-0.005^{*} \\
(0.003)\end{array}$ & $\begin{array}{l}-2.957 \\
(3.098)\end{array}$ & $\begin{array}{l}-23.430 * * * \\
(6.677)\end{array}$ \\
\hline 19 Jul 2012 / (E3) & $\begin{array}{l}-0.011^{* * *} \\
(0.003)\end{array}$ & $\begin{array}{l}-0.239 \\
(0.667)\end{array}$ & $\begin{array}{l}1.477 \\
(1.523)\end{array}$ & $\begin{array}{l}-0.010^{* * *} \\
(0.003)\end{array}$ & $\begin{array}{l}-0.030 \\
(1.852)\end{array}$ & $\begin{array}{l}-1.036 \\
(0.646)\end{array}$ & $\begin{array}{l}-0.007 \\
(0.006)\end{array}$ & $\begin{array}{l}-3.430 \\
(3.744)\end{array}$ & $\begin{array}{l}-20.206^{* *} \\
(8.133)\end{array}$ \\
\hline 23 Aug 2012 / (E4) & $\begin{array}{l}-0.001 \\
(0.002)\end{array}$ & $\begin{array}{l}-2.735^{* * *} \\
(0.391)\end{array}$ & $\begin{array}{l}-5.132 * * * \\
(0.943)\end{array}$ & $\begin{array}{l}0.002 \\
(0.004)\end{array}$ & $\begin{array}{l}-0.105 \\
(1.588)\end{array}$ & $\begin{array}{l}1.811 \\
(1.818)\end{array}$ & $\begin{array}{l}0.003 \\
(0.003)\end{array}$ & $\begin{array}{l}6.917 * * \\
(3.081)\end{array}$ & $\begin{array}{l}-3.522 \\
(7.126)\end{array}$ \\
\hline 1 Feb 2013 / (E5) & $\begin{array}{l}-0.003 \\
(0.003)\end{array}$ & $\begin{array}{l}-2.769 * * * \\
(0.618)\end{array}$ & $\begin{array}{l}-6.626^{* * * *} \\
(1.181)\end{array}$ & $\begin{array}{l}-0.005^{*} \\
(0.003)\end{array}$ & $\begin{array}{l}-1.271^{*} \\
(0.712)\end{array}$ & $\begin{array}{l}-0.106 \\
(3.229)\end{array}$ & $\begin{array}{l}-0.011^{* *} \\
(0.006)\end{array}$ & $\begin{array}{l}-2.244 * * \\
(0.899)\end{array}$ & $\begin{array}{l}-6.890^{* *} \\
(2.775)\end{array}$ \\
\hline 11 Feb 2013 / (E6) & $\begin{array}{l}0.011 * * * \\
(0.003)\end{array}$ & $\begin{array}{l}1.697 * * * \\
(0.303)\end{array}$ & $\begin{array}{l}3.848 * * * \\
(0.671)\end{array}$ & $\begin{array}{l}0.006 * * * \\
(0.002)\end{array}$ & $\begin{array}{l}1.429 * * * \\
(0.256)\end{array}$ & $\begin{array}{l}1.825 * * * \\
(0.626)\end{array}$ & $\begin{array}{l}0.009 \\
(0.008)\end{array}$ & $\begin{array}{l}-0.269 \\
(1.730)\end{array}$ & $\begin{array}{l}1.228 \\
(1.391)\end{array}$ \\
\hline 18 Mar 2013 / (E7) & $\begin{array}{l}-0.015^{* * *} \\
(0.002)\end{array}$ & $\begin{array}{l}-3.338 * * * \\
(0.566)\end{array}$ & $\begin{array}{l}-5.447 * * * \\
(0.873)\end{array}$ & $\begin{array}{l}-0.009 * * * \\
(0.002)\end{array}$ & $\begin{array}{l}-3.400^{* * * *} \\
(0.921)\end{array}$ & $\begin{array}{l}-3.501 * * \\
(1.442)\end{array}$ & $\begin{array}{l}-0.010^{* * *} \\
(0.003)\end{array}$ & $\begin{array}{l}-4.478^{* * *} \\
(1.104)\end{array}$ & $\begin{array}{l}-6.463 * * * \\
(1.976)\end{array}$ \\
\hline 25 Mar 2013 / (E8) & $\begin{array}{l}-0.011^{* * *} \\
(0.003)\end{array}$ & $\begin{array}{l}-5.286^{* * *} \\
(0.771)\end{array}$ & $\begin{array}{l}-7.051 * * * \\
(1.097)\end{array}$ & $\begin{array}{l}-0.013 * * * \\
(0.002)\end{array}$ & $\begin{array}{l}-3.873 * * * \\
(1.123)\end{array}$ & $\begin{array}{l}-5.187 * * * \\
(1.598)\end{array}$ & $\begin{array}{l}-0.023^{* * *} \\
(0.006)\end{array}$ & $\begin{array}{l}-1.745 \\
(2.665)\end{array}$ & $\begin{array}{l}-3.669 * \\
(2.091)\end{array}$ \\
\hline 4 Aug 2014 / (E9) & $\begin{array}{l}0.001 \\
(0.002)\end{array}$ & $\begin{array}{l}0.860 * * * \\
(0.170)\end{array}$ & $\begin{array}{l}1.029 * * * \\
(0.256)\end{array}$ & $\begin{array}{l}-0.006 \\
(0.005)\end{array}$ & $\begin{array}{l}2.872 \\
(2.088)\end{array}$ & $\begin{array}{l}3.571 \\
(2.838)\end{array}$ & $\begin{array}{l}-0.004 \\
(0.003)\end{array}$ & $\begin{array}{l}0.707 * \\
(0.394)\end{array}$ & $\begin{array}{l}0.550 \\
(0.709)\end{array}$ \\
\hline 29 Dec 2016 / (E10) & $\begin{array}{l}-0.004 * * * \\
(0.001)\end{array}$ & $\begin{array}{l}0.373 * \\
(0.198)\end{array}$ & $\begin{array}{l}0.203 \\
(0.464)\end{array}$ & $\begin{array}{l}-0.005^{* * *} \\
(0.001)\end{array}$ & $\begin{array}{l}-0.198 \\
(0.379)\end{array}$ & $\begin{array}{l}0.252 \\
(0.227)\end{array}$ & $\begin{array}{l}-0.007 * * \\
(0.003)\end{array}$ & $\begin{array}{l}1.835^{* *} \\
(0.724)\end{array}$ & $\begin{array}{l}3.880 * * \\
(1.828)\end{array}$ \\
\hline 7 Jun 2017 / (E11) & $\begin{array}{l}0.007 * * * \\
(0.002)\end{array}$ & $\begin{array}{l}0.565^{* *} \\
(0.278)\end{array}$ & $\begin{array}{l}0.916^{* *} \\
(0.410)\end{array}$ & $\begin{array}{l}0.004 * \\
(0.002)\end{array}$ & $\begin{array}{l}0.403 * * \\
(0.187)\end{array}$ & $\begin{array}{l}-0.053 \\
(0.217)\end{array}$ & $\begin{array}{l}0.003 \\
(0.003)\end{array}$ & $\begin{array}{l}0.979 * * \\
(0.463)\end{array}$ & $\begin{array}{l}4.319 * \\
(2.325)\end{array}$ \\
\hline 23 Jun 2017 / (E12) & $\begin{array}{l}-0.001 * * \\
(0.001)\end{array}$ & $\begin{array}{l}2.333 * * * \\
(0.575)\end{array}$ & $\begin{array}{l}4.951 * * * \\
(1.320)\end{array}$ & $\begin{array}{l}-0.002 \\
(0.001)\end{array}$ & $\begin{array}{l}1.459 * * * \\
(0.394)\end{array}$ & $\begin{array}{l}2.744 * * \\
(1.142)\end{array}$ & $\begin{array}{l}-0.001 \\
(0.001)\end{array}$ & $\begin{array}{l}-0.260 \\
(2.191)\end{array}$ & $\begin{array}{l}3.749 * * * \\
(1.345)\end{array}$ \\
\hline 7 Jun 2017 / (E12) & $\begin{array}{l}0.006 * * * \\
(0.001)\end{array}$ & $\begin{array}{l}0.397 \\
(0.283)\end{array}$ & $\begin{array}{l}-0.740 \\
(0.565)\end{array}$ & $\begin{array}{l}0.004 * * * \\
(0.001)\end{array}$ & $\begin{array}{l}-0.040 \\
(0.351)\end{array}$ & $\begin{array}{l}-0.161 \\
(0.369)\end{array}$ & $\begin{array}{l}0.005^{*} \\
(0.003)\end{array}$ & $\begin{array}{l}-0.445 \\
(0.315)\end{array}$ & $\begin{array}{l}-3.877 * \\
(2.020)\end{array}$ \\
\hline 23 Jun 2017 / (E13) & $\begin{array}{l}-0.001 \\
(0.001)\end{array}$ & $\begin{array}{l}0.408^{* *} \\
(0.176)\end{array}$ & $\begin{array}{l}0.608 \\
(0.420)\end{array}$ & $\begin{array}{l}-0.003^{* *} \\
(0.001)\end{array}$ & $\begin{array}{l}-0.002 \\
(0.115)\end{array}$ & $\begin{array}{l}-0.032 \\
(0.203)\end{array}$ & $\begin{array}{l}-0.000 \\
(0.001)\end{array}$ & $\begin{array}{l}-0.143 \\
(0.188)\end{array}$ & $\begin{array}{l}-0.550 \\
(0.432)\end{array}$ \\
\hline 24 Feb 2018 / (E14) & $\begin{array}{l}-0.003 \\
(0.002)\end{array}$ & $\begin{array}{l}-0.039 \\
(0.384)\end{array}$ & $\begin{array}{l}-0.323 \\
(0.462)\end{array}$ & $\begin{array}{l}0.002 \\
(0.001)\end{array}$ & $\begin{array}{l}-0.487 * * * \\
(0.125)\end{array}$ & $\begin{array}{l}-0.564 * \\
(0.313)\end{array}$ & $\begin{array}{l}0.003 * \\
(0.002)\end{array}$ & $\begin{array}{l}-0.424^{* *} \\
(0.198)\end{array}$ & $\begin{array}{l}-0.488 \\
(0.324)\end{array}$ \\
\hline 15 Aug 2019 / (E15) & $\begin{array}{l}0.000 \\
(0.001)\end{array}$ & $\begin{array}{l}-0.393^{*} \\
(0.220)\end{array}$ & $\begin{array}{l}-0.280 \\
(0.242)\end{array}$ & $\begin{array}{l}-0.001 \\
(0.001)\end{array}$ & $\begin{array}{l}-0.553 * * * \\
(0.056)\end{array}$ & $\begin{array}{l}-0.686^{* * *} \\
(0.120)\end{array}$ & $\begin{array}{l}0.001 \\
(0.002)\end{array}$ & $\begin{array}{l}-0.639^{* * * *} \\
(0.108)\end{array}$ & $\begin{array}{l}-0.830 * * * \\
(0.191)\end{array}$ \\
\hline 5 Dec 2019 / (E16) & $\begin{array}{l}-0.007 * * * \\
(0.002)\end{array}$ & $\begin{array}{l}0.179 * * \\
(0.089)\end{array}$ & $\begin{array}{l}0.145 \\
(0.103)\end{array}$ & $\begin{array}{l}-0.001 \\
(0.002)\end{array}$ & $\begin{array}{l}0.037 \\
(0.035)\end{array}$ & $\begin{array}{l}-0.501 \\
(0.476)\end{array}$ & $\begin{array}{l}0.011 \\
(0.011)\end{array}$ & $\begin{array}{l}0.705 \\
(0.578)\end{array}$ & $\begin{array}{l}0.943 \\
(0.921)\end{array}$ \\
\hline 18 Mar 2020 / (E17) & $\begin{array}{l}0.004 \\
(0.003)\end{array}$ & $\begin{array}{l}-1.084 * * * \\
(0.329)\end{array}$ & $\begin{array}{l}-0.928 * * \\
(0.442)\end{array}$ & $\begin{array}{l}0.003 \\
(0.002)\end{array}$ & $\begin{array}{l}0.624 \\
(0.594)\end{array}$ & $\begin{array}{l}-0.794 \\
(1.057)\end{array}$ & $\begin{array}{l}0.003 \\
(0.002)\end{array}$ & $\begin{array}{l}1.752 * * \\
(0.782)\end{array}$ & $\begin{array}{l}2.974 \\
(1.967)\end{array}$ \\
\hline
\end{tabular}

Events selected based on [28] and updates based on Single Resolution Board and European Commission (EC) press releases. Results for an event window of $-1 /+1$ day, that is including three observations. "Senior" ("Subord") denotes coefficient estimates for changes in CDS price quotes for senior unsecured (subordinated) debt; all such changes are multiplied through by minus one to make the estimates comparable in interpretation to those obtained for equity prices. Thus, a negative sign means that CDS spreads are rising, which can be interpreted as "bad news" for debt holders. Source: Authors' estimates 


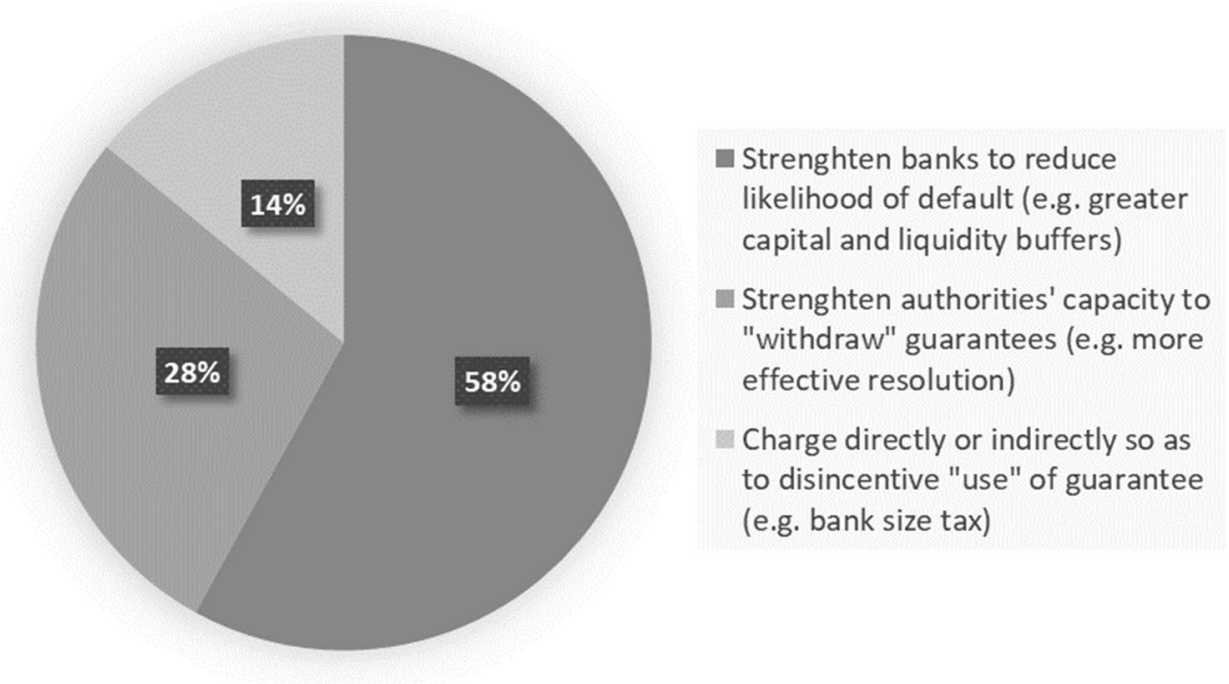

Fig. 3 Self-assessment by public authorities of description of mix of domestic regulatory reforms with a potential bearing on the value of implicit bank debt guarantees, as of 2014 Note: Percentages of responses indicating what policy makers considered to be "very relevant" as description of the gist of their regulatory reform response to the global financial crisis with a bearing on the value of implicit bank debt guarantees (alternative allowed responses are "moderately relevant" and "not relevant", with results not shown here). The presentation of the above results implicitly assumes that the three types of policies are exclusive. This assumption is maintained in the present work, although it is acknowledged that there is some overlap among types of measures (although exploration of such overlaps are left for subsequent work). The figure is based on responses from altogether

and the strength of the respective sovereign, are shown in Table 3.

The estimates need to be interpreted differently depending on which of the three types of policy measures is considered. As regards announcements of policies of type 1 ("making banks safer"), the effect is not clear a priori, however. On the one hand, credible measures reduce the probability of default, which tends to reduce the risk premium as the perceived guarantee moves further "out of the money". This effect would be accompanied by a decrease in the risk premium and a positive coefficient estimate (i.e. a decrease in CDS quotes). On the other hand, a negative coefficient estimate implies an increase in CDS quotes and an increase in risk premia. Such an outcome might reflect the view that the announcements to make banks safer are interpreted by

\footnotetext{
${ }^{10}$ CDS spread reactions are multiplied through by minus one, so as to ensure that results are more easily comparable with those obtained for equity price changes, which are the traditional focus of event studies. Thus, a negative sign implies an increase in risk premium for debt and a decrease in equity return. We suggest, however, to primarily focus on the results for debt as those are more directly linked to the value of implicit bank debt guarantees, as opposed to equity prices, although we report also the latter to facilitate comparison with previous empirical studies.
}

33 of (then) 34 OECD member countries and two partner countries to a survey by the OECD Committee on Financial Markets on "policy responses to the issue of implicit bank debt guarantees" completed in 2014. Respondents were asked to describe the overall thrust of the mix of policy measures that they have either implemented, where three categories were offered alternatively for the responses following feedback from respondents. These are "very relevant", "moderately relevant" and "not relevant". The questionnaire acknowledged that even if many of the regulatory reform measures were not exclusively geared towards reducing the value of implicit guarantees, they would be expected to have an effect on such values as they affect the costs, returns and risks of bank business activities. Source: [30]

market participants as signalling public authorities' stance regarding resolution practices. In particular, by announcing measures to make banks stronger, authorities might also be seen as signalling a reduced willingness to provide for an implicit guarantee should the increased strength turn out to be ultimately insufficient to avoid failure. In fact, it turns out that the results are mixed in the sense that the estimated signs of coefficients for measures to make banks safer can have opposing signs and even be significant in different directions. To the extent that announcements are considered credible in the case of policies of type 2 ("making banks more resolvable") and 3 ("charging banks for implicit guarantee"), the coefficient estimates for senior and subordinated debt CDS would be expected to be (significantly) negative. ${ }^{10}$ Such a market reaction is thus consistent with an increase in the risk premium on debt. It turns out that this is often but not always the case.

Consider the example of announcements related to the new common European resolution framework, that is, the EU Finance Ministers' agreement on the European Banking Recovery and Resolution Directive (BRRD, on 28 June 2013) and the various steps to complete the Single Resolution Mechanism (SRM; 9 July 2013, 18 December 2013, 
Table 3 Market reactions to actions regarding potential bank resolution across types of banks

\begin{tabular}{|c|c|c|c|c|}
\hline Date / Event ID & Event & Equity & Senior & Subord \\
\hline \multicolumn{5}{|c|}{ Announcements related to measures to make banks safer } \\
\hline 17 Dec 2009 & BIS: Enhance capital, liquidity and introduce leverage ratios & $\begin{array}{l}-0.006^{* * * *} \\
(0.002)\end{array}$ & $\begin{array}{l}0.543 * * * \\
(0.174)\end{array}$ & $\begin{array}{l}0.358 \\
(0.334)\end{array}$ \\
\hline 27 Jun 2010 & G20: Toronto summit backs enhanced bank capital requirement & $\begin{array}{l}-0.000 \\
(0.001)\end{array}$ & $\begin{array}{l}0.260 \\
(0.513)\end{array}$ & $\begin{array}{l}0.272 \\
(0.579)\end{array}$ \\
\hline 30 Aug 2020 & $\mathrm{CH}$ too-big-to-fail regulation: Equity up to $25 \%$ & $\begin{array}{l}-0.002^{* *} \\
(0.001)\end{array}$ & $\begin{array}{l}-0.495 \\
(0.311)\end{array}$ & $\begin{array}{l}-0.507 \\
(0.400)\end{array}$ \\
\hline 7 Sep 2010 & $\mathrm{CH}$ too-big-to-fail regulation: Big banks need more capital & $\begin{array}{l}-0.006 * * * \\
(0.001)\end{array}$ & $\begin{array}{l}-1.485^{* * *} \\
(0.349)\end{array}$ & $\begin{array}{l}-1.515^{* * *} \\
(0.546)\end{array}$ \\
\hline 12 Sep 2010 & Basel III: Fixing of the equity requirements & $\begin{array}{l}0.004 * * * \\
(0.001)\end{array}$ & $\begin{array}{l}1.504 * * * \\
(0.216)\end{array}$ & $\begin{array}{l}2.264 * * * \\
(0.334)\end{array}$ \\
\hline 16 Dec 2010 & $\begin{array}{l}\text { Publication "Basel III: A global regulatory framework for more resilient banks and } \\
\text { banking systems" }\end{array}$ & $\begin{array}{l}-0.011 * * * \\
(0.002)\end{array}$ & $\begin{array}{l}-1.571 * * * \\
(0.423)\end{array}$ & $\begin{array}{l}-3.178^{* *} \\
(1.262)\end{array}$ \\
\hline 27 Jun 2011 & BCBS proposal of additional capital surcharges of 1.0 to $2.5 \%$ Common Tier 1 & $\begin{array}{l}-0.004 * * * \\
(0.001)\end{array}$ & $\begin{array}{l}-3.669 * * * \\
(0.914)\end{array}$ & $\begin{array}{l}-6.725^{* * * *} \\
(1.847)\end{array}$ \\
\hline 19 Jul 2011 & $\begin{array}{l}\text { BCBS Consultative paper on G-SIB Assessment Methodology \& FSB Consultative } \\
\text { paper of effective resolution of SIFIs }\end{array}$ & $(0.001)$ & $\begin{array}{l}-2.302 \\
(1.404)\end{array}$ & $\begin{array}{l}-3.322^{*} \\
(1.800)\end{array}$ \\
\hline 29 Sep 2011 & BCBS announces endorsement of proposal on additional capital surcharges & $\begin{array}{l}0.009 * * * \\
(0.002)\end{array}$ & $\begin{array}{l}2.896 * * * \\
(1.079)\end{array}$ & $\begin{array}{l}-2.412 \\
(2.959)\end{array}$ \\
\hline 21 Jan 2010 & Refom proposals by Vickers and Volcker & $\begin{array}{l}-0.003 * * \\
(0.001)\end{array}$ & $\begin{array}{l}-1.919 * * * \\
(0.258)\end{array}$ & $\begin{array}{l}-3.396 * * * \\
(0.689)\end{array}$ \\
\hline 22 Apr 2010 & $\mathrm{CH}$ too-big-to-fail regulation: Press conference on preliminary too-big-to-fail report & $\begin{array}{l}-0.003 * * * \\
(0.001)\end{array}$ & $\begin{array}{l}-3.251^{* * *} \\
(0.813)\end{array}$ & $\begin{array}{l}-2.731 * * * \\
(0.695)\end{array}$ \\
\hline 16 Jun 2010 & Vickers reform proposal: Appointing the Vickers Commission & $\begin{array}{l}0.002 * * \\
(0.001)\end{array}$ & $\begin{array}{l}0.021 \\
(0.612)\end{array}$ & $\begin{array}{l}0.829 \\
(0.704)\end{array}$ \\
\hline 5 Aug 2010 & Vickers reform proposal & $\begin{array}{l}0.001 \\
(0.001)\end{array}$ & $\begin{array}{l}-0.439 * * \\
(0.179)\end{array}$ & $\begin{array}{l}0.716 \\
(0.588)\end{array}$ \\
\hline 4 Oct 2010 & $\mathrm{CH}$ too-big-to-fail regulation: Press conference-presenting the final report & $\begin{array}{l}0.003 * * * \\
(0.001)\end{array}$ & $\begin{array}{l}1.975 * * * \\
(0.316)\end{array}$ & $\begin{array}{l}2.187 * * * \\
(0.333)\end{array}$ \\
\hline 12 Nov 2010 & $\begin{array}{l}\text { Endorsement of core elements for enhanced supervision, resolution and loss absorbency } \\
\text { tools at 5th G20 summit in Seoul }\end{array}$ & $\begin{array}{l}-0.003 * * * \\
(0.001)\end{array}$ & $\begin{array}{l}-1.219 * * * \\
(0.469)\end{array}$ & $\begin{array}{l}-1.497 * * * \\
(0.556)\end{array}$ \\
\hline 21 Dec 2010 & $\mathrm{CH}$ too-big-to-fail regulation: Swiss federal council adopts draft of law for large banks & $\begin{array}{l}0.001 \\
(0.001)\end{array}$ & $\begin{array}{l}-1.570^{* * *} \\
(0.386)\end{array}$ & $\begin{array}{l}-3.552 * \\
(1.874)\end{array}$ \\
\hline 18 Jan 2011 & Vickers reform proposal: Vickers tends to split up big banks & $\begin{array}{l}0.005^{* * * *} \\
(0.001)\end{array}$ & $\begin{array}{l}1.564 * * * \\
(0.557)\end{array}$ & $\begin{array}{l}5.669 * * * \\
(1.913)\end{array}$ \\
\hline 15 Jun 2011 & Vickers reform proposal: Osborne's pre-approval of the ringfencing approach & $\begin{array}{l}-0.001 \\
(0.001)\end{array}$ & $\begin{array}{l}-1.396 * \\
(0.715)\end{array}$ & $\begin{array}{l}-3.298^{*} \\
(1.735)\end{array}$ \\
\hline 12 Sep 2011 & Vickers reform proposal: Publication of the Vickers report & $\begin{array}{l}-0.000 \\
(0.002)\end{array}$ & $\begin{array}{l}-4.924 * * * \\
(1.214)\end{array}$ & $\begin{array}{l}-9.451 * * * \\
(1.889)\end{array}$ \\
\hline 28 Jun 2013 & EU Finance Ministers agree on rules of BRRD & $\begin{array}{l}-0.005^{* * *} \\
(0.001)\end{array}$ & $\begin{array}{l}0.628 * * \\
(0.281)\end{array}$ & $\begin{array}{l}0.271 \\
(1.352)\end{array}$ \\
\hline 9 Jul 2013 & Presentation of the SRM proposal by European Commission & $\begin{array}{l}-0.002 \\
(0.002)\end{array}$ & $\begin{array}{l}0.634 * \\
(0.381)\end{array}$ & $\begin{array}{l}1.040 * * \\
(0.451)\end{array}$ \\
\hline 18 Dec 2013 & EU Council accepts general approach towards SRM & $\begin{array}{l}-0.001 \\
(0.001)\end{array}$ & $\begin{array}{l}1.755 * * * \\
(0.337)\end{array}$ & $\begin{array}{l}2.324 * * * \\
(0.441)\end{array}$ \\
\hline 20 Mar 2014 & Provisional agreement on the SRM between Council and European Parliament & $\begin{array}{l}-0.003 \\
(0.002)\end{array}$ & $\begin{array}{l}0.145 \\
(0.162)\end{array}$ & $\begin{array}{l}0.435 * \\
(0.230)\end{array}$ \\
\hline
\end{tabular}


Table 3 (continued)

\begin{tabular}{|c|c|c|c|c|}
\hline Date / Event ID & Event & Equity & Senior & Subord \\
\hline 15 Apr 2014 & EU Parliament backs EC proposal on completing the SRM & $\begin{array}{l}-0.004 * * * \\
(0.001)\end{array}$ & $\begin{array}{l}0.341 * * \\
(0.134)\end{array}$ & $\begin{array}{l}0.087 \\
(0.199)\end{array}$ \\
\hline \multicolumn{5}{|c|}{ Announcements related to measures to charge banks for implicit guarantee } \\
\hline 8 Mar 2010 & German reform Constitutional experts: A bank tax is juridical feasible & $\begin{array}{l}-0.001 \\
(0.001)\end{array}$ & $\begin{array}{l}0.930 * * * \\
(0.325)\end{array}$ & $\begin{array}{l}1.590 * * * \\
(0.353)\end{array}$ \\
\hline 21 Mar 2010 & German reform: Governing coalition urges for bank tax & $\begin{array}{l}0.001 \\
(0.001)\end{array}$ & $\begin{array}{l}0.004 \\
(0.158)\end{array}$ & $\begin{array}{l}-0.761 * * * \\
(0.232)\end{array}$ \\
\hline 31 Mar 2010 & German reform: Key points for bank tax and restructuring law agreed by the cabinet & $\begin{array}{l}-0.002 \\
(0.002)\end{array}$ & $\begin{array}{l}-0.338^{* *} \\
(0.162)\end{array}$ & $\begin{array}{l}-0.979 * * * \\
(0.217)\end{array}$ \\
\hline 25 Aug 2010 & German reform: Bank tax and restructuring law passed by the federal cabinet & $\begin{array}{l}0.001 \\
(0.001)\end{array}$ & $\begin{array}{l}-1.759 * * * \\
(0.319)\end{array}$ & $\begin{array}{l}-2.465^{* * *} \\
(0.532)\end{array}$ \\
\hline
\end{tabular}

Events selected based on [21, 29, 28] and updates based on Single Resolution Board and European Commission (EC) press releases. Results for an event window of $-1 /+1$ day, that is including three observations. "Senior" ("Subord") denotes coefficient estimates for changes in CDS price quotes for senior unsecured (subordinated) debt; all such changes are multiplied through by minus one to make the estimates comparable in interpretation to those obtained for equity prices. Thus, a negative sign means that CDS spreads are rising, which can be interpreted as "bad news" for debt holders. Source: Authors' estimates

20 March 2014, 15 April 2014). It turns out that for these events, while bank equity can sometimes significantly underperform the market, there is no evidence that any of these events were seen as "bad news" for senior or subordinated bank debt holders. Risk premia on such debt did not increase significantly. In fact, on the occasion of the Council of the European Union agreement on the general approach towards the SRM, including the application of BRRD rules, both senior and subordinated debt even outperformed the broader market, as reflected in significant declines in risk premia. This observation would be consistent with "positive news" for debt holders. One possible interpretation is that the new framework of centralised bail-in was not considered credible, which in turn might have implied that the issue of how to finance the resolution fund remained unsolved. In fact, as already noted by [29], the European Central Bank (ECB) explicitly expressed such concerns with regard to the agreed framework. Incidentally, [29] also find that bank spreads decline following the EU Council announcement regarding SRM on 18 December 2013, although not significantly. By contrast, the estimates in Table 3 suggest that the declines of both spreads on senior and subordinated debt are significant. Incidentally, our results also differ from [29] in that we fail to identify a significant increase in bank CDS spreads following the announcement on 20 March 2014, unlike these authors. Our results even suggest that subordinated bank debt outperformed the market following that announcement. In any case, taken the various evidence in the present estimates together, debt market reactions do not provide convincing evidence that announcements related to the new resolution framework (including BRRD and SRM) are reflected in significant increases in risk premia on subordinated or senior bank debt.
The results might reflect to some extent the limits of the event study method. Such an approach is perhaps less useful for the evaluation of regulatory and policy announcements as opposed to specific resolution actions, as the former are part of a gradual negotiation process, which tends to be accompanied by continuing adaptations and revisions of expectations. As a result, the "news" element of each of these various announcements is more limited as they are part of a gradually evolving process, which is unlike the case of resolution actions.

\section{Market reactions to actions versus announcements}

Table 4 compares the aggregate results for bank failure resolution actions (henceforth referred to as "actions") with those for the three different types of regulatory and policy announcements, that is to make banks stronger, more resolvable or taxing them for the implicit guarantee (henceforth referred to as "announcements"). Among the control variables, the size of banks turns out to be significant only for the equity. By contrast, the overall market change is significantly positively correlated with changes in bank debt CDS, as expected. Bank CDS changes are also significantly positively correlated with those in sovereign CDS prices, which suggests that a decoupling of domestic banks from their respective sovereign has not been achieved in Europe as of yet.

Actions are, on aggregate, reflected in significant increases in the risk premium on senior and subordinated bank debt. This observation is remarkable, given that in the case of two out of the twelve events, significant declines as opposed to increases of the risk premium were observed. These included the "no-action" in the case of Banca 
Table 4 Market reactions to "actions" versus "announcements"

\begin{tabular}{|c|c|c|c|}
\hline Variables & Equity & Senior & Subord \\
\hline Actions & $\begin{array}{l}-0.002 * * * \\
(0.000)\end{array}$ & $\begin{array}{l}-0.426^{* *} \\
(0.208)\end{array}$ & $\begin{array}{l}-1.450 * * * \\
(0.309)\end{array}$ \\
\hline Announcements related to measures to make banks stronger (announcements of type I) & $\begin{array}{l}-0.001 * \\
(0.001)\end{array}$ & $\begin{array}{l}-0.415 \\
(0.271)\end{array}$ & $\begin{array}{l}-1.663 * * * \\
(0.599)\end{array}$ \\
\hline Announcements related to measures to make banks more resolvable (announcements of type II) & $\begin{array}{l}-0.001 * * \\
(0.000)\end{array}$ & $\begin{array}{l}-0.414 * * * \\
(0.136)\end{array}$ & $\begin{array}{l}-0.572 * \\
(0.314)\end{array}$ \\
\hline Announcements related to charges for the implicit guarantee (announcements of type III) & $\begin{array}{l}0.000 \\
(0.001)\end{array}$ & $\begin{array}{l}-0.291 * * * \\
(0.103)\end{array}$ & $\begin{array}{l}-0.655^{* * *} \\
(0.167)\end{array}$ \\
\hline Equity market index (MSCI) & $\begin{array}{l}1.316^{* * * *} \\
(0.048)\end{array}$ & & \\
\hline Bank size (logarithm of Total Assets) & $\begin{array}{l}0.000 * * \\
(0.000)\end{array}$ & $\begin{array}{l}0.008 \\
(0.009)\end{array}$ & $\begin{array}{l}0.011 \\
(0.015)\end{array}$ \\
\hline Return on sovereign senior CDS & $\begin{array}{l}0.000 * * * \\
(0.000)\end{array}$ & $\begin{array}{l}0.317 * * * \\
(0.040)\end{array}$ & $\begin{array}{l}0.394 * * * \\
(0.086)\end{array}$ \\
\hline CDS market index (Itraxx Senior) & & $\begin{array}{l}0.674 * * * \\
(0.053)\end{array}$ & $\begin{array}{l}0.937 * * * \\
(0.091)\end{array}$ \\
\hline Constant & $\begin{array}{l}-0.003^{* *} \\
(0.001)\end{array}$ & $\begin{array}{l}-0.077 \\
(0.128)\end{array}$ & $\begin{array}{l}-0.075 \\
(0.219)\end{array}$ \\
\hline Observations & 115,242 & 118,874 & 115,725 \\
\hline Number of id & 44 & 44 & 44 \\
\hline Adj R2 & 0.303 & 0.199 & 0.125 \\
\hline Ncluster & 44 & 44 & 44 \\
\hline
\end{tabular}

Robust standard errors in parentheses. ${ }^{* *} p<0.01,{ }^{* *} p<0.05,{ }^{*} p<0.1$

Popolare di Vicenza and Veneto Banca on 23 June 2017 (see Table 1). By contrast, in the case of three other events, significant increases in the spread for subordinated debt could be observed, and thus, the overall effect, on aggregate, of actions on the risk premium in subordinated debt is significantly positive. That is, risk premia increase.

Different types of announcements are associated with different market reactions. Announcements regarding measures to make banks stronger and more resolvable are associated with an increase in the risk premium for either subordinated debt or both debt, respectively. Announcements that suggest to make banks stronger ("announcements of type I"), e.g. by increasing core capital, imply a significant increase in spreads for subordinated debt, but not for senior debt. A possible interpretation is that such measures are accompanied by the implicit assumption that whenever the increased buffers would turn out to be insufficient ex post, public authorities will impose burden sharing on debtors and subordinated debt will be first in line. Announcements of intent to make bank more resolvable ("announcements of type II"), by contrast, are associated with increased spreads on both senior and subordinated debt. This finding might reflect a view that such announcements make bail-in of senior debt more likely, while that of subordinated debt is already considered as likely to be bailed in as part of a potential bank failure resolution. Finally, announcements that imply imposing some form of charge for implicit guarantees ("announcements of type III") are associated with increases in risk premia on both senior and subordinated debt. Thus, it might seem that the announcement of this type of policy action has a particularly strong effect on risk premia in bank debt. That said, it should be noted that all events in this category of policy options relate to a single jurisdiction and that there is no evidence that similar results might apply in other countries.

As noted previously, regulatory reforms have effectively created different types of banks (i.e. G-SIBs, other SIBs (O-SIBs) and non-SIBs), with regulatory requirements differing for each type. Distinguishing among the types of banks, Table 5 shows that actions as well as announcements to make banks more resolvable are associated mostly with significantly negative debt market reactions, although exceptions include the cases of senior and subordinated debt for G-SIBs. The distinction between the three types of banks also reveals that announcements to charge a tax for implicit guarantees, which are associated with a significant negative market reaction (as shown in Table 4), owe this effect mainly to the results for G-SIBs and O-SIBs.

Moreover, it appears that for any type of event (either actions or announcements), the effects on the debt of G-SIBs are economically less important than for the other two 
Table 5 Market reactions to different types of policy and regulatory announcements

\begin{tabular}{|c|c|c|c|c|c|c|c|c|c|}
\hline \multirow[t]{2}{*}{ Variables } & \multicolumn{3}{|l|}{ G-SIBs } & \multicolumn{3}{|l|}{ O-SIBs } & \multicolumn{3}{|c|}{ Non-O-SIBs } \\
\hline & Equity & Senior & Subord & Equity & Senior & Subord & Equity & Senior & Subord \\
\hline Actions & $\begin{array}{l}-0.001 * * * \\
(0.000)\end{array}$ & $\begin{array}{l}-0.648 * * * \\
(0.119)\end{array}$ & $\begin{array}{l}-1.185^{* * * *} \\
(0.221)\end{array}$ & $\begin{array}{l}-0.002 * * * \\
(0.001)\end{array}$ & $\begin{array}{l}-0.273 \\
(0.187)\end{array}$ & $\begin{array}{l}-0.408 \\
(0.349)\end{array}$ & $\begin{array}{l}-0.003 * * * \\
(0.001)\end{array}$ & $\begin{array}{l}-0.375 \\
(0.697)\end{array}$ & $\begin{array}{l}-3.264 * * * \\
(0.796)\end{array}$ \\
\hline Announc. & -0.001 & $0.617 * * *$ & $0.485 * *$ & -0.000 & -0.502 & $-1.593 * *$ & $-0.004 * *$ & $-1.709 * * *$ & $-4.938 * * *$ \\
\hline Type I & $(0.001)$ & $(0.152)$ & $(0.218)$ & $(0.001)$ & $(0.438)$ & $(0.708)$ & $(0.002)$ & $(0.597)$ & (1.605) \\
\hline Announc. & $-0.002 * * *$ & $-0.288^{*}$ & $-0.749 * * *$ & $-0.001 * *$ & -0.227 & -0.446 & 0.001 & $-0.855 * *$ & -0.515 \\
\hline Type II & $(0.001)$ & $(0.151)$ & $(0.252)$ & $(0.001)$ & $(0.145)$ & $(0.624)$ & $(0.001)$ & $(0.334)$ & $(0.608)$ \\
\hline Announc. & -0.000 & $-0.396 * * *$ & $-0.740 * * *$ & -0.001 & $-0.325^{*}$ & $-0.691 * *$ & 0.001 & -0.092 & -0.464 \\
\hline Type III & $(0.001)$ & $(0.112)$ & $(0.205)$ & $(0.001)$ & $(0.183)$ & $(0.308)$ & $(0.002)$ & $(0.336)$ & $(0.460)$ \\
\hline Obs & 115,242 & 118,874 & 115,725 & 115,242 & 118,874 & 115,725 & 115,242 & 118,874 & 115,725 \\
\hline
\end{tabular}

Robust standard errors in parentheses. ${ }^{* * *} p<0.01,{ }^{* *} p<0.05,{ }^{*} p<0.1$

groups of entities, as judged by the size of the estimated coefficients. We conjecture that this observation reflects in part the fact that G-SIBs tend to be better capitalised, especially towards the later part of our sample period, and perhaps are therefore less sensitive to news regarding regulatory announcements or resolution actions.

\section{Lack of transparency as explanation of the mixed results?}

For the TBTF reforms to achieve their desired effects, bank counterparties, including investors and depositors, need sufficient information; this observation points to the crucial relevance of the issue of transparency. Failure resolution mechanisms are part of the financial safety net, which is meant to protect the system, and to achieve its function requires transparency regarding the conditions and the limits of the financial safety net. In fact, to address the moral hazard that is created by making available any insurance function, standard economic theory suggests that coverage needs to be limited and that the limits of that coverage be well understood by the potential beneficiary. For example, debt instruments not covered by the perimeter of the financial safety net need to carry adequate risk premia. To allow for this to happen, different requirements need to be met.

First, sufficient information is needed about the quality and quantity of bank liquidity and capital buffers, so that investors can develop informed views about the riskiness and potential losses associated with investments in different types of bank liabilities, including equity, senior and subordinated debt. An understanding of the extent and timing of the waterfall of potential losses in case of failure is a prerequisite for investors to ask for risk premia on different types of bank liability investments. Unfortunately, information about Total Loss Absorbency Capital (TLAC) or Minimum Requirement for own funds and Eligible Liabilities (MREL) in the European Union, can be difficult to compare across institutions and jurisdictions.

Second, bank counterparties might need sufficient information about the authorities' own assessment of the extent to which bank counterparties in turn perceive the new regime to function as desired. In particular, to the extent that public authorities are confident that bank counterparties ex ante do not assume the existence of implicit subsidies, they should feel confident about not providing any support ex post. To the extent that public authorities credibly communicate their own assessment of perceptions regarding implicit guarantees (see, however, for challenges Sect. 2.2) the scope for any potential time inconsistency problem would be limited. This observation in turn would imply that public authorities' communication influences bank counterparty expectations and behaviour, including their demand of risk premia.

Third, sufficient information is needed about the resolution options available and authorities' preferred resolution strategies given the specific mix of the holders of bail-inable subordinated and senior debt. In other words, how authorities would pick and choose among the available resolution tools in practice, given the distribution of exposures among bank counterparties, and what the choice would imply in terms of loss distribution among bank counterparties. As a general rule, even in the case of authorities' assessments of resolvability of systemically important banks, details are not fully spelled out and shared beyond the members of a specific crisis management group. As a general rule, more transparency about the structure of bank creditors and where bank recovery or resolution bail-in losses may go would be desirable. Increasing transparency in this regard would help assure policy makers that the new tools available can be used effectively and smoothly in actual practice [7].

To the extent that investors in bail-inable bank debt are aware of the associated risk the credibility of the bail-in framework is enhanced. In fact, one challenge of implementing bail-in in the past was that retail investors that would 
Table 6 Relative costs of protection and selected decisions regarding (potential) bank failure resolution

\begin{tabular}{|c|c|c|c|c|c|}
\hline Date & Event & All banks & G-SIBs & O-SIBs & Non-SIBs \\
\hline 6 Feb 2011 & Bail-in of senior debtors of Amagerbanken in Denmark & $\begin{array}{l}0.011 \\
(0.012)\end{array}$ & $\begin{array}{l}-0.016 \\
(0.016)\end{array}$ & $\begin{array}{l}-0.006 \\
(0.018)\end{array}$ & $\begin{array}{l}0.070 * * \\
(0.029)\end{array}$ \\
\hline $10 \mathrm{Jul} 2012$ & Spanish bank rescue plan implies bail-in of junior creditors & $\begin{array}{l}-0.009 \\
(0.016)\end{array}$ & $\begin{array}{l}0.006 \\
(0.019)\end{array}$ & $\begin{array}{l}-0.041^{*} \\
(0.021)\end{array}$ & $\begin{array}{l}0.019 \\
(0.045)\end{array}$ \\
\hline 19 Jul 2012 & $\begin{array}{l}\text { German government back Spanish rescue plan foreseeing bail-in of junior } \\
\text { creditors }\end{array}$ & $\begin{array}{l}0.008 \\
(0.014)\end{array}$ & $\begin{array}{l}0.010 \\
(0.019)\end{array}$ & $\begin{array}{l}-0.024 \\
(0.020)\end{array}$ & $\begin{array}{l}0.051 \\
(0.037)\end{array}$ \\
\hline 23 Aug 2012 & $\begin{array}{l}\text { Spanish authorities clearly express intent to implement national bank resolution } \\
\text { law }\end{array}$ & $\begin{array}{l}0.022 \\
(0.016)\end{array}$ & $\begin{array}{l}0.015 \\
(0.019)\end{array}$ & $\begin{array}{l}-0.004 \\
(0.022)\end{array}$ & $\begin{array}{l}0.071 \\
(0.044)\end{array}$ \\
\hline 1 Feb 2013 & Nationalisation of SNS Reaal in the Netherlands & $\begin{array}{l}0.008 \\
(0.013)\end{array}$ & $\begin{array}{l}0.027 \\
(0.018)\end{array}$ & $\begin{array}{l}0.001 \\
(0.020)\end{array}$ & $\begin{array}{l}-0.005 \\
(0.034)\end{array}$ \\
\hline 11 Feb 2013 & $\begin{array}{l}\text { Euro area finance ministers consider bail-in of senior debt as option for Cyprus } \\
\text { banks }\end{array}$ & $\begin{array}{l}0.008 \\
(0.014)\end{array}$ & $\begin{array}{l}0.024 \\
(0.021)\end{array}$ & $\begin{array}{l}0.004 \\
(0.020)\end{array}$ & $\begin{array}{l}-0.007 \\
(0.033)\end{array}$ \\
\hline 18 Mar 2013 & $\begin{array}{l}\text { Cyprian proposal to introduce levy including on insured Cyprian bank deposi- } \\
\text { tors }\end{array}$ & $\begin{array}{l}-0.003 \\
(0.014)\end{array}$ & $\begin{array}{l}0.017 \\
(0.019)\end{array}$ & $\begin{array}{l}-0.021 \\
(0.020)\end{array}$ & $\begin{array}{l}-0.003 \\
(0.039)\end{array}$ \\
\hline 25 Mar 2013 & Bail-in of senior debtors of Cyprian banks & $\begin{array}{l}-0.008 \\
(0.017)\end{array}$ & $\begin{array}{l}0.007 \\
(0.019)\end{array}$ & $\begin{array}{l}-0.032 * \\
(0.019)\end{array}$ & $\begin{array}{l}0.005 \\
(0.050)\end{array}$ \\
\hline 4 Aug 2014 & Creditor bail-in in the case of Banco Espirito Santo, Portugal & $\begin{array}{l}-0.077 * * * \\
(0.012)\end{array}$ & $\begin{array}{l}-0.098 * * * \\
(0.017)\end{array}$ & $\begin{array}{l}-0.042^{* *} \\
(0.018)\end{array}$ & $\begin{array}{l}-0.099 * * * \\
(0.028)\end{array}$ \\
\hline 29 Dec 2016 & "Precautionary recapitalisation" of Banca Monte dei Paschi & $\begin{array}{l}-0.002 \\
(0.016)\end{array}$ & $\begin{array}{l}-0.009 \\
(0.034)\end{array}$ & $\begin{array}{l}0.005 \\
(0.018)\end{array}$ & $\begin{array}{l}-0.005 \\
(0.032)\end{array}$ \\
\hline 7 Jun 2017 & $\begin{array}{l}\text { SRB transfers all shares and debt of Banco Popular Español to Banco San- } \\
\text { tander }\end{array}$ & $\begin{array}{l}0.008 \\
(0.015)\end{array}$ & $\begin{array}{l}0.003 \\
(0.026)\end{array}$ & $\begin{array}{l}0.024 \\
(0.017)\end{array}$ & $\begin{array}{l}-0.009 \\
(0.036)\end{array}$ \\
\hline 23 Jun 2017 & $\begin{array}{l}\text { SRB not to take resolution action re Banca Popolare di Vicenza and Veneto } \\
\text { Banca }\end{array}$ & $\begin{array}{l}0.029 * \\
(0.017)\end{array}$ & $\begin{array}{l}0.035 \\
(0.033)\end{array}$ & $\begin{array}{l}0.030 \\
(0.023)\end{array}$ & $\begin{array}{l}0.020 \\
(0.036)\end{array}$ \\
\hline 4 Jul 2017 & EC announced the approval of the precautionary recapitalisation of MPS & $\begin{array}{l}0.059 * * * \\
(0.017)\end{array}$ & $\begin{array}{l}0.056 \\
(0.034)\end{array}$ & $\begin{array}{l}0.047 * \\
(0.024)\end{array}$ & $\begin{array}{l}0.081 * * * \\
(0.030)\end{array}$ \\
\hline 24 Feb 2018 & $\begin{array}{l}\text { SRB not to take resolution action re ABLV Bank and its subsidiary in Luxem- } \\
\text { bourg }\end{array}$ & $\begin{array}{l}0.083 * * * \\
(0.018)\end{array}$ & $\begin{array}{l}0.050 \\
(0.031)\end{array}$ & $\begin{array}{l}0.088 * * * \\
(0.031)\end{array}$ & $\begin{array}{l}0.118 * * * \\
(0.033)\end{array}$ \\
\hline 15 Aug 2019 & $\begin{array}{l}\text { SRB not to take action re AS PNB Banka, to be wound up national law in } \\
\text { Latvia }\end{array}$ & $\begin{array}{l}0.110 * * * \\
(0.022)\end{array}$ & $\begin{array}{l}0.125 * * * \\
(0.042)\end{array}$ & $\begin{array}{l}0.144 * * * \\
(0.030)\end{array}$ & $\begin{array}{l}0.040 \\
(0.042)\end{array}$ \\
\hline 5 Dec 2019 & EC approves NordLB State aid & $\begin{array}{l}0.108 * * * \\
(0.021)\end{array}$ & $\begin{array}{l}0.135 * * * \\
(0.037)\end{array}$ & $\begin{array}{l}0.135 * * * \\
(0.032)\end{array}$ & $\begin{array}{l}0.034 \\
(0.040)\end{array}$ \\
\hline 18 Mar 2020 & SRB: No compensation due to Banco Popular counterparties & $\begin{array}{l}0.121 * * * \\
(0.021)\end{array}$ & $\begin{array}{l}0.160 * * * \\
(0.032)\end{array}$ & $\begin{array}{l}0.155^{* * * *} \\
(0.037)\end{array}$ & $\begin{array}{l}0.020 \\
(0.041)\end{array}$ \\
\hline
\end{tabular}

Events as in Table 1. Dependent variable is the ratio of CDS prices of subordinated debt minus CDS prices of senior debt divided by CDS prices of subordinated debt of the same bank

have been involved in the burden sharing, including in particular as subordinated debt holders, might not have been fully informed of the associated risks. Such considerations should, however, not necessarily determine bank failure resolution approaches, and one could argue that any losses that are considered undesirable on the basis of consumer protection concerns could in principle be subsequently compensated through specific transfers.

One observation is that the costs of protection of subordinated debt as opposed to senior debt have noticeably increased on average over all banks during our sample period (Fig. 4). The observation that the price of protection of subordinated as opposed to senior debt has risen could be interpreted as indicating that investors more fully appreciate that subordinated debt tends to be riskier than senior debt. Such a development would be desirable. Another interpretation might be, however, that investors believe that senior debt has become relatively more protected from bail-in, for example as a result of a policy preference for the so-called contained bail-in, in which equity and subordinated debt are bailed in but not senior debt [24]. If accurate, that development might indicate that parts of the value of implicit guarantees on subordinated debt have migrated to senior debt.

Table 6 shows the results of the baseline regression that includes, as dependent variable, the ratio of (i) CDS prices of subordinated debt minus CDS prices of senior debt (ii) 


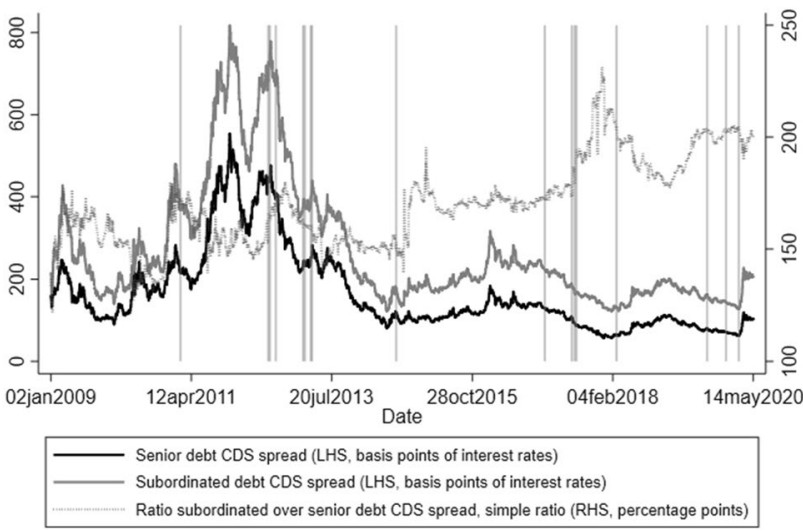

Fig. 4 Ratio of subordinated versus senior debt CDS spreads. Note: Vertical bar indicate dates of bank failure resolution actions as listed in Tables 1 and 6. Source: Authors' estimates

divided by CDS prices of subordinated debt of the same bank. The bail-in of creditors of Banco Espirito Santo on 4 August 2014 is accompanied by a significant reduction of the ratio of subordinated over senior CDS spreads. Otherwise, no significant effect on that ratio is identified during the earlier part of our sample until the 4 July 2017 , that is the approval of the precautionary recapitalisation of Monte dei Paschi. For that as well as for all four subsequent events, the CDS ratio increases significantly. This observation indicates that as a result of each of these events subordinated debt is considered as having become more risky as compared to senior debt than was the case prior to each of these events. As regards the results for subgroups, the direction of effects were mostly similar across the three different types of banks (with the exception of the case of Amagerbanken), although estimates were not always significant for each and every of the three groups of banks whenever they were significant for the full sample of banks.

The finding in Table 6 is consistent with the results suggesting that the notion of a "contained bail-in" is becoming more credible [24], that is a bail-in that tends to focus primarily on subordinated debt but tends to protect (be "contained" vis-à-vis) senior debtors. Neuberg et al. [24] distinguish three potential outcomes, that is, (i) full bail-in, (ii) contained bail-in and (iii) full bail-out. The increase in the subordinated-to-senior CDS ratio is consistent with either a greater likelihood of either one of the first two outcomes, but not the third. Unfortunately, the data considered for the present analysis does not allow us to assess what might happen to the likelihood of each individual of these three potential outcomes, however. That said, the evidence presented here is consistent with the hypothesis that subordinated debt has become more risky, while senior debt remains unchanged or is (even seen as having become) less risky.

The presence of systemic risk in situations of negative system-wide shocks might explain that there are some limitations to a fully transparent bail-in policy affecting all classes of bank liabilities [2]. In fact, when it comes to monetary and fiscal policy, a clear consensus has been reached over the last decades in favour of transparency, as opposed to "constructive ambiguity", to make these policies efficient. This development owes much to the insight that economic agents monitor the behaviour of public authorities and form their own views about the expected behaviour. They thus anticipate and can offset the effects of discretionary policies. Under those circumstances, the best choice is for public authorities to determine and disseminate clear rules, and to establish credibility by acting consistently and transparently. The so-called constructive ambiguity in monetary and fiscal policy is hardly mentioned anymore these days.

The assessment might have to be nuanced slightly, however, when it comes to the operation of the financial safety net that backs the activities of financial intermediaries that take deposits and on-lend these funds and continue to be a crucial part of the financial system. While rigid safety net rules can limit any bias towards ad hoc extensions of safety net provisions, it is impossible to anticipate the nature of financial problems and the extent to which they might become systemic. Even when private markets are efficient, costly bank failures can occur, and public authorities who have not pre-committed to any specific course of failure resolution action are still likely to bail out distressed banks to limit such costs [8]. Under those circumstances, announcing and trying to follow very transparent pre-specified rules creates the risk that if and when public authorities do not follow them, they will lose credibility. Thus, some room for manoeuvre might be considered helpful, especially to the extent that there continues to be opacity about the various contagion mechanisms, making it unlikely that failure will be limited to just one institution. Unfortunately, however, resolution authorities' discretion in using the bail-in tool, e.g. by deciding to exempt senior bank debt on some occasions, limits predictability of resolution outcomes and thus the effectiveness of market discipline [35]. To influence expectations, rules must be understood and verifiable.

\section{Conclusions}

The empirical results herein are consistent with progress being made in reducing the value of implicit bank debt guarantees, especially on more subordinated bank liabilities. Some bank failure resolution actions seem to have significantly raised risk premia on subordinated or senior unsecured bank debt. Noticeable examples include the cases of bail-in of junior creditors in Spain and junior and senior creditors in Cyprus in 2012 and 2013, respectively. More recent cases involving potential bail-in of creditors seem to have, however, had no effect on risk premia on junior or 
senior debt, or might even have had an effect in the opposite direction. The explanation might be that the action in those cases essentially consisted of no-action; that is, they did not involve any bail-in unlike what might have been expected beforehand and based on the experience with the cases mentioned above. Resolution actions seem to have considerable effects on market perceptions of risk premia on junior and senior bank debt, but the reactions of such risk premia to policy and regulatory announcements are more difficult to explain. No clear pattern seems to be emerging, with results being partly contradictory among different events for any specific type of regulatory or policy announcements.

\section{Appendix 1}

See Table 7.

Table 7 Selected empirical studies of the funding cost advantages

\begin{tabular}{|c|c|c|c|c|c|c|c|c|c|c|c|c|c|}
\hline \multirow[t]{2}{*}{ Study, sample or approach } & \multicolumn{13}{|c|}{ Implicit subsidy in basis points of interest rates } \\
\hline & 2007 & 2008 & 2009 & 2010 & 2011 & 2012 & 2013 & 2014 & 2015 & 2016 & 2017 & 2018 & 2019 \\
\hline [19], UK large banks sample & & 100 & 200 & & & & & & & & & & \\
\hline UK small banks sample & & 100 & 100 & & & & & & & & & & \\
\hline [26], contingent claims & & & & 8 & & & & & & & & & \\
\hline Sveriges Riksbank (2011) & 86 & 86 & 86 & 86 & 86 & 86 & & & & & & & \\
\hline [25], ratings-based & & & & 54 & & & & & & & & & \\
\hline Contingent claims, assumption I & & & & 175 & & & & & & & & & \\
\hline Contingent claims, assumption II & & & & 36 & & & & & & & & & \\
\hline Contingent claims, assumption III & & & & 29 & & & & & & & & & \\
\hline [22], European banks & 3 & 50 & 50 & 50 & & & & & & & & & \\
\hline [36], ratings-based & 60 & & 90 & & & & & & & & & & \\
\hline [33], ratings-based & 111 & 120 & 157 & 156 & 109 & 110 & & & & & & & \\
\hline$[4]$ & & 5 & 16 & 15 & 31 & 30 & & & & & & & \\
\hline [20], Euro area, ratings-based & 21 & 45 & 92 & 74 & 74 & 61 & 62 & & & & & & \\
\hline Japan, ratings-based & 18 & 31 & 65 & 53 & 44 & 25 & 24 & & & & & & \\
\hline UK, ratings-based & 8 & 18 & 35 & 23 & 22 & 17 & 16 & & & & & & \\
\hline US, ratings-based & 6 & 8 & 19 & 19 & 13 & 14 & 12 & & & & & & \\
\hline Euro area, contingent claims & 10 & 16 & 22 & 14 & -10 & 91 & 86 & & & & & & \\
\hline Japan, contingent claims & 29 & 99 & 137 & 115 & 79 & 80 & 63 & & & & & & \\
\hline UK, contingent claims & 10 & 34 & 22 & -3 & 0 & 79 & 62 & & & & & & \\
\hline US, contingent claims & 3 & 19 & 43 & 24 & 15 & 15 & 13 & & & & & & \\
\hline [27], bond spread-based & & & 27 & 7 & -5 & 11 & 1 & & & & & & \\
\hline [17], contingent claims min & 34 & 38 & 37 & 33 & 35 & 33 & 32 & 32 & 31 & & & & \\
\hline contingent claims, $\max$ & 39 & 146 & 170 & 38 & 41 & 38 & 38 & 37 & 37 & & & & \\
\hline [37], international banks and insurers & 1 & 13 & 13 & 26 & 26 & 26 & 26 & & & & & & \\
\hline [23], large Canadian banks, Moody’s & 22 & 22 & 20 & 19 & 19 & 17 & 18 & 18 & 18 & 13 & 26 & & \\
\hline large Canadian banks, S\&P & & & & & & 5 & 17 & 22 & 22 & 22 & 22 & & \\
\hline [16], European banks & & & 401 & 180 & 254 & 343 & 148 & 94 & 91 & 100 & & & \\
\hline [10], Australian D-SIBs & -17 & 24 & 36 & 53 & 38 & 29 & 23 & 11 & 16 & 19 & 24 & & \\
\hline [5], Sweden, contingent claims & & & 330.4 & 199.9 & 144.0 & 93.3 & 2.8 & 2.8 & 29.5 & 81.6 & 24.8 & 38.7 & \\
\hline based on CDS pricing & & & 23.3 & 12.8 & & & & & & & & 5.3 & \\
\hline rating-based & & & 321.9 & 220.3 & 24.6 & 37.6 & 25.5 & 9.3 & 6.4 & 10.6 & 8.6 & 6.6 & \\
\hline [14] & 179 & 218 & 210 & 123 & 190 & 177 & 132 & 134 & 143 & 61 & -12 & 23 & 11 \\
\hline
\end{tabular}

Authors' selection of studies. Some studies include several estimates reported above. Blix-Grimaldi et al. [5] consider three different estimation approaches. FSB[14] considers a global portfolio (Asia, Europe, USA, Canada); SIBs (that is G-SIBs and D-SIBs) versus non-SIB large banks. Annualised averages of monthly estimates kindly obtained from Asani Sarkar. Source: Update from [30] 


\section{Appendix 2}

See Table 8 .

Table 8 Effects of country-specific events on domestic versus foreign banks

\begin{tabular}{|c|c|c|c|c|c|c|c|}
\hline \multirow[t]{2}{*}{ Date } & \multirow[t]{2}{*}{ Event } & \multicolumn{2}{|l|}{ Equity } & \multicolumn{2}{|l|}{ Senior } & \multicolumn{2}{|c|}{ Subordinated } \\
\hline & & Baseline & Country effect & Baseline & Country effect & Baseline & Country effect \\
\hline \multirow[t]{2}{*}{08.03 .2010} & $\begin{array}{l}\text { German reform Constitutional experts: A } \\
\text { bank tax is juridical feasible }\end{array}$ & -0.000 & $0.004 * * *$ & $0.861 * * *$ & 0.567 & $1.609 * * *$ & 0.632 \\
\hline & & $(0.001)$ & $(0.001)$ & $(0.261)$ & $(0.687)$ & $(0.341)$ & $(1.048)$ \\
\hline \multirow[t]{2}{*}{ 21.03.2010 } & $\begin{array}{l}\text { German reform: Governing coalition urges } \\
\text { for bank tax }\end{array}$ & 0.001 & $0.006 * *$ & 0.012 & 0.078 & $-0.794 * * *$ & $-1.240 * * *$ \\
\hline & & $(0.001)$ & $(0.002)$ & $(0.124)$ & $(0.184)$ & $(0.215)$ & $(0.144)$ \\
\hline \multirow[t]{2}{*}{31.03 .2010} & $\begin{array}{l}\text { German reform: Key points for bank tax } \\
\text { and restructuring law agreed by the } \\
\text { cabinet }\end{array}$ & -0.001 & $-0.010^{* *}$ & $-0.343^{* *}$ & $-1.447 * *$ & $-1.039 * * *$ & $-0.938 * * *$ \\
\hline & & $(0.002)$ & $(0.004)$ & $(0.136)$ & $(0.678)$ & $(0.195)$ & $(0.306)$ \\
\hline \multirow[t]{2}{*}{25.08 .2010} & $\begin{array}{l}\text { German reform: Bank tax and restructuring } \\
\text { law passed by the federal cabinet }\end{array}$ & 0.001 & $-0.005^{*}$ & $-1.763^{* * *}$ & -0.423 & $-2.698 * * *$ & $-1.382 * * *$ \\
\hline & & $(0.001)$ & $(0.003)$ & $(0.253)$ & $(0.687)$ & $(0.466)$ & $(0.228)$ \\
\hline \multirow[t]{2}{*}{ 19.07.2012 } & $\begin{array}{l}\text { German government backs Spanish bank } \\
\text { rescue plan }\end{array}$ & $-0.009 * * *$ & $-0.007 * * *$ & -1.061 & $-1.931^{* *}$ & $-5.105^{* * *}$ & -0.354 \\
\hline & & $(0.002)$ & $(0.002)$ & $(1.230)$ & $(0.900)$ & $(1.958)$ & $(1.048)$ \\
\hline 5.12 .2019 & EC approves NordLB State aid & $\begin{array}{l}0.000 \\
(0.001)\end{array}$ & $\begin{array}{l}0.001 * * * \\
(0.000)\end{array}$ & $\begin{array}{l}-0.512 * * * \\
(0.082)\end{array}$ & $\begin{array}{l}-0.117 * * \\
(0.054)\end{array}$ & $\begin{array}{l}-0.590 * * * \\
(0.100)\end{array}$ & $\begin{array}{l}0.431 * * * \\
(0.111)\end{array}$ \\
\hline \multirow[t]{2}{*}{22.04 .2010} & $\begin{array}{l}\mathrm{CH} \text { too-big-to-fail regulation: Press confer- } \\
\text { ence on preliminary too-big-to-fail report }\end{array}$ & $-0.004 * * *$ & $-0.008^{*}$ & $-3.169 * * *$ & $-3.942 * *$ & $-2.956^{* * *}$ & $-3.544 * *$ \\
\hline & & $(0.001)$ & $(0.004)$ & $(0.510)$ & $(1.892)$ & $(0.625)$ & $(1.563)$ \\
\hline \multirow[t]{2}{*}{30.08 .2010} & $\begin{array}{l}\mathrm{CH} \text { too-big-to-fail regulation: Equity up to } \\
25 \%\end{array}$ & $-0.002 * *$ & -0.002 & $-0.483^{*}$ & $-0.305 * * *$ & $-0.651^{*}$ & $-0.911 * * *$ \\
\hline & & $(0.001)$ & $(0.002)$ & $(0.272)$ & $(0.086)$ & $(0.382)$ & $(0.182)$ \\
\hline \multirow[t]{2}{*}{ 07.09.2010 } & $\begin{array}{l}\mathrm{CH} \text { too-big-to-fail regulation: Big banks } \\
\text { need more capital }\end{array}$ & $-0.006^{* * *}$ & $-0.013 * * *$ & $-1.465^{* * *}$ & $-2.438 * * *$ & $-1.537 * * *$ & $-1.825^{* * *}$ \\
\hline & & $(0.001)$ & $(0.002)$ & $(0.254)$ & $(0.230)$ & $(0.518)$ & $(0.302)$ \\
\hline \multirow[t]{2}{*}{04.10 .2010} & $\begin{array}{l}\mathrm{CH} \text { too-big-to-fail regulation: Press confer- } \\
\text { ence-presenting the final report }\end{array}$ & $0.002 * * *$ & $0.003 * * *$ & $1.968 * * *$ & $1.712 * * *$ & $2.289 * * *$ & $2.684 * * *$ \\
\hline & & $(0.001)$ & $(0.000)$ & $(0.231)$ & $(0.177)$ & $(0.215)$ & $(0.307)$ \\
\hline \multirow[t]{2}{*}{ 21.12.2010 } & $\begin{array}{l}\mathrm{CH} \text { too-big-to-fail regulation: Swiss federal } \\
\text { council adopts draft of law for large banks }\end{array}$ & 0.001 & $-0.003 * * *$ & $-1.506^{* * *}$ & $0.228 * * *$ & -3.616 & $-2.592 * * *$ \\
\hline & & $(0.001)$ & $(0.000)$ & $(0.321)$ & $(0.063)$ & (2.743) & $(0.089)$ \\
\hline \multirow[t]{2}{*}{16.06 .2010} & $\begin{array}{l}\text { Vickers reform proposal: Appointing the } \\
\text { Vickers Commission }\end{array}$ & $0.002 * *$ & $0.008 * *$ & 0.143 & -1.062 & $0.972 *$ & -0.326 \\
\hline & & $(0.001)$ & $(0.004)$ & $(0.384)$ & (1.068) & (0.499) & $(0.424)$ \\
\hline \multirow[t]{2}{*}{ 05.08.2010 } & $\begin{array}{l}\text { Vickers reform proposal: Barclays warns to } \\
\text { leave UK in case of a bank break-up }\end{array}$ & 0.001 & 0.001 & $-0.440 * * *$ & $-0.911^{*}$ & 0.627 & 0.453 \\
\hline & & $(0.001)$ & $(0.004)$ & $(0.162)$ & $(0.531)$ & $(0.552)$ & (1.134) \\
\hline \multirow[t]{2}{*}{ 18.01.2011 } & $\begin{array}{l}\text { Vickers reform proposal: Vickers tends to } \\
\text { split up big banks }\end{array}$ & $0.005 * * *$ & $-0.006^{* *}$ & $1.541 * * *$ & $1.248 * *$ & $5.287 * * *$ & $5.401 * * *$ \\
\hline & & $(0.001)$ & (0.003) & $(0.320)$ & $(0.509)$ & (1.120) & $(2.081)$ \\
\hline \multirow[t]{2}{*}{15.06 .2011} & $\begin{array}{l}\text { Vickers reform proposal: Osborne's pre- } \\
\text { approval of the ringfencing approach }\end{array}$ & -0.001 & 0.000 & $-1.320^{*}$ & 0.327 & $-3.461 * * *$ & -3.018 \\
\hline & & $(0.001)$ & $(0.002)$ & $(0.705)$ & $(0.497)$ & (1.316) & (1.974) \\
\hline
\end{tabular}


Table 8 (continued)

\begin{tabular}{|c|c|c|c|c|c|c|c|}
\hline \multirow[t]{2}{*}{ Date } & \multirow[t]{2}{*}{ Event } & \multicolumn{2}{|l|}{ Equity } & \multicolumn{2}{|l|}{ Senior } & \multicolumn{2}{|c|}{ Subordinated } \\
\hline & & Baseline & Country effect & Baseline & Country effect & Baseline & Country effect \\
\hline \multirow[t]{2}{*}{ 12.09.2011 } & $\begin{array}{l}\text { Vickers reform proposal: Publication of the } \\
\text { Vickers report }\end{array}$ & -0.001 & $0.006 * * *$ & $-4.931 * * *$ & $-4.093 * *$ & $-9.482 * * *$ & $-9.571 * * *$ \\
\hline & & $(0.002)$ & $(0.002)$ & $(0.918)$ & $(1.786)$ & $(1.792)$ & $(2.558)$ \\
\hline \multirow[t]{2}{*}{ 10.07.2012 } & $\begin{array}{l}\text { Spanish bank rescue plan implies junior } \\
\text { creditor bail-in }\end{array}$ & -0.001 & $-0.006^{*}$ & $-1.852 * *$ & 2.567 & $-10.06^{* * *}$ & $-32.50 * * *$ \\
\hline & & $(0.001)$ & (0.004) & $(0.884)$ & (4.014) & $(1.470)$ & (7.136) \\
\hline \multirow[t]{2}{*}{ 23.08.2012 } & $\begin{array}{l}\text { Spanish authorities express intent to imple- } \\
\text { ment national bank resolution law }\end{array}$ & 0.002 & 0.011 & $1.542 *$ & $14.351 * * *$ & -2.070 & $7.813^{* *}$ \\
\hline & & $(0.001)$ & $(0.007)$ & $(0.881)$ & $(3.522)$ & (1.907) & (3.172) \\
\hline \multirow[t]{2}{*}{ 06.07.2017 } & $\begin{array}{l}\text { SRB transferred shares of Banco Popular to } \\
\text { Santander. }\end{array}$ & $0.005 * * *$ & 0.004 & $0.619 * * *$ & $1.998 * * *$ & $1.505^{* *}$ & $6.585^{* *}$ \\
\hline & & $(0.001)$ & $(0.004)$ & $(0.145)$ & $(0.595)$ & $(0.621)$ & (3.217) \\
\hline \multirow[t]{2}{*}{ 18.03.2020 } & $\begin{array}{l}\text { SRB: No compensation due to Banco Popu- } \\
\text { lar counterparties }\end{array}$ & 0.000 & -0.002 & $0.260 *$ & 0.108 & 0.129 & -0.896 \\
\hline & & $(0.002)$ & $(0.003)$ & $(0.136)$ & $(0.181)$ & $(0.271)$ & $(0.797)$ \\
\hline \multirow[t]{2}{*}{01.02 .2013} & $\begin{array}{l}\text { Nationalisation of SNS Reaal in the Neth- } \\
\text { erlands }\end{array}$ & $-0.006 * * *$ & $-0.012 * * *$ & $-2.064 * * *$ & $-3.660 * * *$ & $-4.326 * * *$ & $-8.743 * * *$ \\
\hline & & $(0.002)$ & $(0.000)$ & $(0.310)$ & $(0.081)$ & $(1.024)$ & $(0.145)$ \\
\hline \multirow[t]{2}{*}{04.08 .2014} & $\begin{array}{l}\text { Creditor bail-in in case of Banco Espirito } \\
\text { Santo, Portugal }\end{array}$ & $-0.003^{*}$ & -0.036 & $1.624 * *$ & 14.301 & $1.800^{* *}$ & 18.995 \\
\hline & & $(0.002)$ & $(0.026)$ & $(0.652)$ & $(9.296)$ & $(0.836)$ & $(12.514)$ \\
\hline \multirow[t]{2}{*}{ 29.12.2016 } & $\begin{array}{l}\text { "Precautionary recapitalisation" of Banca } \\
\text { Monte dei Paschi }\end{array}$ & $-0.005^{* * *}$ & $-0.015 * * *$ & $0.532 * *$ & $0.660 * * *$ & $1.214 * *$ & $1.234 * *$ \\
\hline & & $(0.001)$ & $(0.003)$ & $(0.254)$ & $(0.159)$ & $(0.544)$ & $(0.575)$ \\
\hline \multirow[t]{2}{*}{ 23.06.2017 } & $\begin{array}{l}\text { The SRB will not take resolution action in } \\
\text { relation to Banca Popolare di Vicenza and } \\
\text { Veneto Banca }\end{array}$ & $-0.002 * *$ & 0.002 & $1.263 * *$ & $4.819 * * *$ & $3.798 * * *$ & $9.442 * * *$ \\
\hline & & $(0.001)$ & $(0.003)$ & $(0.623)$ & $(1.604)$ & $(0.626)$ & $(2.278)$ \\
\hline \multirow[t]{2}{*}{ 04.07.2017 } & $\begin{array}{l}\text { EC announced the approval of the precau- } \\
\text { tionary recapitalisation of MPS }\end{array}$ & $0.005 * * *$ & $0.008 * *$ & -0.013 & 0.135 & $-1.413^{* *}$ & -1.520 \\
\hline & & $(0.001)$ & $(0.003)$ & $(0.183)$ & $(0.216)$ & $(0.633)$ & $(2.675)$ \\
\hline \multirow[t]{2}{*}{06.02 .2011} & $\begin{array}{l}\text { Bail-in of senior debt of Amagerbanken in } \\
\text { Denmark }\end{array}$ & $0.003^{* *}$ & $-0.017 * * *$ & 0.194 & $-0.493 * * *$ & 0.049 & $-0.901 * * *$ \\
\hline & & $(0.001)$ & $(0.000)$ & $(0.267)$ & $(0.035)$ & $(0.419)$ & $(0.063)$ \\
\hline
\end{tabular}

Open Access This article is licensed under a Creative Commons Attribution 4.0 International License, which permits use, sharing, adaptation, distribution and reproduction in any medium or format, as long as you give appropriate credit to the original author(s) and the source, provide a link to the Creative Commons licence, and indicate if changes were made. The images or other third party material in this article are included in the article's Creative Commons licence, unless indicated otherwise in a credit line to the material. If material is not included in the article's Creative Commons licence and your intended use is not permitted by statutory regulation or exceeds the permitted use, you will need to obtain permission directly from the copyright holder. To view a copy of this licence, visit http://creativecommons.org/licenses/by/4.0/.

\section{References}

1. Admati, A. R., DeMarzo, P. M., Hellwig, M. F., Pfleiderer, P., et al. (2010). Fallacies, irrelevant facts, and myths in the discussion of capital regulation: Why bank equity is not expensive, volume 86. Max Planck Inst. for Research on Collective Goods.

2. Beck, T., Radev, D., and Schnabel, I. (2020). Bank resolution regimes and systemic risk.

3. Benczur, P., Cannas, G., Cariboni, J., Di Girolamo, F., Maccaferri, S., and Giudici, M. P. (2017). Evaluating the effectiveness of the new eu bank regulatory framework: A farewell to bail-out? Journal of Financial Stability, 33:207-223. 
4. Bijlsma, M. J. and Mocking, R. (2013). The private value of toobig-to-fail guarantees.

5. Blix-Grimaldi, M., Crosta, D., and Linder, J. (2019). The value of an implicit state guarantee for systemic banks. Swedish National Debt Office and Swedish Financial Supervisory Authority, Focus Repor.

6. Calomiris, C. W. (1999). Building an incentive-compatible safety net. Journal of Banking \& Finance, 23(10), 1499-1519.

7. Cariboni, J., Fontana, A., Langedijk, S., Maccaferri, S., Pagano, A., Giudici, M. P., Rancan, M., and Schich, S. (2016). Reducing and sharing the burden of bank failures. OECD Journal: Financial Market Trends, 2015(2), 29-61.

8. Chari, V. V. and Kehoe, P. J. (2016). Bailouts, time inconsistency, and optimal regulation: A macroeconomic view. American Economic Review, 106(9), 2458-93.

9. Cubillas, E., Fernández, A. I., and González, F. (2017). How credible is a too-big-to-fail policy? international evidence from market discipline. Journal of Financial Intermediation, 29:46-67.

10. Cummings, J. R. and Guo, Y. (2020). Do the basel iii capital reforms reduce the implicit subsidy of systemically important banks? australian evidence. Pacific-Basin Finance Journal, 59:101247.

11. Deutsche Bundesbank (2016). Magnitude and development of implicit government guarantees for banks. Financial Stability Review.

12. Estrella, A. and Schich, S. (2015). Valuing guaranteed bank debt: The roles of the strength and size of the bank and the guarantor. Journal of Economic \& Financial Studies, 3(05), 19-32.

13. FSB (2021a). Financial Stability Board : Evaluation of the effects of too-big-to-fail reforms: Final report. https://www.fsb. org/2021/03/evaluation-of-the-effects-of-too-big-to-fail-refor ms-final-report/.

14. FSB (2021b). Financial Stability Board : Evaluation of the effects of too-big-to-fail reforms: Technical Appendix. https://www.fsb. org/wp-content/uploads/P280620-2.pdf.

15. Blix-Grimaldi, M., Hofmeister, J., Schich, S., and Snethlage, D. (2017). Estimating the size and incidence of bank resolution costs for selected banks in oecd countries. OECD Journal: Financial Market Trends, 2016(1), 1-36.

16. Groenewegen, J. and Wierts, P. (2017). Two big distortions: Bank incentives for debt financing. Technical report, ESRB Working Paper Series.

17. Gudmundsson, T. (2016). Whose Credit Line is it Anyway: An Update on Banks' Implicit Subsidies. International Monetary Fund.

18. Hagendorff, J., Keasey, K., and Vallascas, F. (2018). When banks grow too big for their national economies: Tail risks, risk channels, and government guarantees. Journal of Financial and Quantitative Analysis, 53(5), 2041-2066.

19. Haldane, A. G. (2010). The $\$ 100$ billion question. Revista de Economía Institucional, 12(22), 83-110.

20. International Monetary Fund (2014). How big is the implicit subsidy for banks considered too important to fail? Global Financial Stability Report, Chapter 3, April.

21. Moenninghoff, S. C., Ongena, S., and Wieandt, A. (2015). The perennial challenge to counter too-big-to-fail in banking: Empirical evidence from the new international regulation dealing with global systemically important banks. Journal of Banking \& Finance, 61:221-236.

22. Moody's (2011). Quantifying the value of implicit government guarantees for large financial institutions. Europe, 44:7772-5454.

23. Mora, P. P. (2018). The" too big to fail" subsidy in canada: Some estimates. Technical report, Bank of Canada Staff Working Paper.

24. Neuberg, R., Glasserman, P., Kay, B., and Rajan, S. (2018). The market-implied probability of government support for distressed european banks. OFR WP, pages 16-10.
25. Noss, J. and Sowerbutts, R. (2012). The implicit subsidy of banks. Bank of England Financial Stability Paper, (15).

26. Oxera (2011). Assessing state support to the uk banking sector.

27. PWC (2014). Bank structural reform study: Supplementary report 1- is there an implicit subsidy for eu banks? Pricewaterhouse Coopers.

28. Schäfer, A., Schnabel, I., and Weder, B. (2016a). Bail-in expectations for european banks: Actions speak louder than words. Technical report, CEPR Discussion Paper No. DP11061.

29. Schäfer, A., Schnabel, I., and Weder di Mauro, B. (2016b). Financial sector reform after the subprime crisis: Has anything happened? Review of Finance, 20(1), 77-125.

30. Schich, S. (2018). Implicit bank debt guarantees: Costs, benefits and risks. Journal of Economic Surveys, 32(5), 1257-1291.

31. Schich, S. and Aydin, Y. (2014). Measurement and analysis of implicit guarantees for bank debt: Oecd survey results. OECD Journal: Financial Market Trends, 2014(1), 39-67.

32. Schich, S. and Kim, B.-H. (2013). Developments in the value of implicit guarantees for bank debt: The role of resolution regimes and practices. OECD Journal: Financial Market Trends, 2012(2), $35-65$.

33. Schich, S. and Lindh, S. (2012). Implicit guarantees for bank debt: Where do we stand? OECD Journal: Financial Market Trends, 2012(1), 45-63.

34. Schweikhard, F. A. and Tsesmelidakis, Z. (2011). The impact of government interventions on cds and equity markets. In Finance Meeting EUROFIDAI-AFFI, Paris, December.

35. Tröger, T. H. (2018). Too complex to work: a critical assessment of the bail-in tool under the european bank recovery and resolution regime. Journal of Financial Regulation, 4(1), 35-72.

36. Ueda, K. and Di Mauro, B. W. (2013). Quantifying structural subsidy values for systemically important financial institutions. Journal of Banking \& Finance, 37(10), 3830-3842.

37. Zhao, L. (2018). Market-based estimates of implicit government guarantees in european financial institutions. European Financial Management, 24(1), 79-112.

Publisher's Note Springer Nature remains neutral with regard to jurisdictional claims in published maps and institutional affiliations.

Mario Bellia joined the Joint Research Centre (JRC) of the European Commission in 2018, where he works on topics related to banking regulation, deposit insurance schemes, and revision of the current BRRD regulation. He works also on cryptoassets, central clearing, high frequency trading and sovereign bond market analysis. From 2013 to 2018 he worked at the Leibniz Institute for Financial Research SAFE in Frankfurt, and he has been appointed as Research Visitor at the European Systemic Risk Board (ESRB) of the European Central Bank. Previously, he was a researcher at the Ca' Foscari University of Venice (Italy). He studied Economics at the Ca' Foscari University of Venice and later obtained a joint Ph.D in Economics from the Goethe University Frankfurt and Ca' Foscari University of Venice. As financial economist, he uses advanced quantitative methods applied to policy and economic dynamics. He has done extensive work in the area of financial stability, simulation of banking losses to estimate counterfactual scenario, estimation of models with high-frequency data at microsecond level and econometric models using panel data.

Sara Maccaferri is currently a senior consultant in Be Consulting, where she is involved in developing and implementing statistical and machine learning models to support the activity of a top-level Italian bank. From 2009 to 2020 she worked as a researcher at the Joint Research Centre of the European Commission, where she supported with quantitative studies the Commission services in the areas of 
strengthening the Banking Union and financial stability. Mrs Maccaferri is a Mathematical Engineer by education and she got a $\mathrm{PhD}$ in Mathematics at the Katholieke Universiteit Leuven.

Sebastian Schich is a Senior Economist in the Policy and Strategy Division of the Economics Department of the European Investment Bank, since 2020, with responsibilities including the evaluation of impact of EIB lending. Principal Economist, from 2003 to 2020, in the OECD Directorate for Financial and Enterprise Affairs, he supported the work of the OECD Committee on Financial Markets (CMF) and its working groups, including the Working Party on Public Debt Management. Also represented the OECD in the Financial Stability Board
Analytical Group on Vulnerabilities and provided leadership on OECD work on financial sector guarantees. Before that, he worked as Economist in the Monetary and Finance Division and Mexico/Portugal Desk of the OECD Economics Department. He worked as economist in the Deutsche Bundesbank from 1994 to 1997, supporting the formulation of and communication about monetary policy and implementing a new method to estimate the term structure of interest rates for the regular monitoring of interest rate developments. He also worked as Associate Economic Affairs Officer at the United Nations Conference on Trade and Development and taught development economics at the London School of Economics and monetary policy at the University of Bonn. 